Working Paper No. 2012/69

\title{
Aid Effectiveness in the Health Sector
}

\author{
Melisa Martínez Álvarez and \\ Arnab Acharya*
}

August 2012

\begin{abstract}
This paper explores the current evidence underlying the debate on aid effectiveness, with a specific focus on the health sector. It summarizes the history of aid and outlines the methodological challenges encountered when assessing its effectiveness. The current evidence on 'what works' in the different aid modalities is outlined, highlighting examples of success. The review finds that resource allocation, lack of predictability of funds, fragmentation, fungibility and the system of relationships foreign aid generates all hinder its effectiveness. Furthermore, even when projects are successful, countries face constraints in scaling them up. The aid effectiveness debate is dynamic, however, and constantly influenced by new global policies and players. The paper ends with a discussion of the future of aid and how these new actors and policies are likely to shape the landscape of development co-operation.
\end{abstract}

Keywords: aid effectiveness, health, fungibility, harmonization JEL classification: O10, O16, O19

\section{Copyright (C) UNU-WIDER 2012}

*both authors London School of Hygiene and Tropical Medicine

This working paper has been prepared within the UNU-WIDER project 'Foreign Aid: Research and Communication (ReCom)', directed by Tony Addison and Finn Tarp. UNU-WIDER gratefully acknowledges specific programme contributions from the governments of Denmark (Ministry of Foreign Affairs, Danida) and Sweden (Swedish International Development Cooperation Agency-Sida) for ReCom. UNU-WIDER also gratefully acknowledges core financial support to UNU-WIDER's work programme from the governments of Finland (Ministry for Foreign Affairs), the United Kingdom (Department for International Development), and the governments of Denmark and Sweden. 
The World Institute for Development Economics Research (WIDER) was established by the United Nations University (UNU) as its first research and training centre and started work in Helsinki, Finland in 1985. The Institute undertakes applied research and policy analysis on structural changes affecting the developing and transitional economies, provides a forum for the advocacy of policies leading to robust, equitable and environmentally sustainable growth, and promotes capacity strengthening and training in the field of economic and social policy making. Work is carried out by staff researchers and visiting scholars in Helsinki and through networks of collaborating scholars and institutions around the world.

www.wider.unu.edu publications@wider.unu.edu

UNU World Institute for Development Economics Research (UNU-WIDER)

Katajanokanlaituri 6 B, 00160 Helsinki, Finland

Typescript prepared by Lorraine Telfer-Taivainen at UNU-WIDER

The views expressed in this publication are those of the author(s). Publication does not imply endorsement by the Institute or the United Nations University, nor by the programme/project sponsors, of any of the views expressed. 
There has been a long history of high-income countries providing development assistance to low- and middle-income countries (LMIC), most pledging to devote 0.7 per cent of their gross domestic product (GDP) for this purpose (Clemens and Moss 2005). Although most countries have not met their target, the amount of development assistance has risen exponentially over the past ten years. This, together with worries about the sustainability of increases in funding given the current economic climate, has resulted in widespread interest on the impact of development assistance, with a growing literature seeking to assess whether it has had any impact on growth and social development. As we shall see below, this literature shows mixed results, hindered by methodological difficulties and lack of data. The aim of this paper is to examine the current evidence regarding the effectiveness of aid in the health sector in order to shed some light on what the current state of knowledge is, and how the future of the aid effectiveness debate looks.

The history of development assistance has taken many turns, with infrastructure and 'hard' sectors being favoured in the earlier decades, and 'softer' social sectors preferred in the first decade of this century. The health sector has received particularly generous funding, having quintupled from US\$5.82 billion in 1990 to US\$27.73 billion in 2011 (Institute for Health Metrics and Evaluation 2011).The amount of development assistance for health (DAH) roughly remained at the 1995 level until 2000 - the new millennium saw a surge in DAH. Secular upward trends occurred from 2002 to today (OECD-DAC data). The prominence of recognition of HIV/AIDS as a global problem resulted in a proportion of DAH going to HIV/AIDS, rising from being around 10 per cent of total amount DAH in 2000 to nearly 40 per cent by 2007 (see Figure 3). Table 1 shows historical trends in DAH from the early 1970s until the present day.

This increase in funds has been accompanied by a proliferation of actors who provide (governments, private foundations, individuals and the corporate sector), manage (bilateral agencies, inter-governmental agencies, global health partnerships, nongovernment organizations (NGOs), private foundations) or spend (DAH (multi-lateral agencies, the UN, global health partnerships, NGOs, private sector, and low- and middle-income governments and civil society organizations) (McCoy et al. 2009). This wide variety of actors deliver development assistance for health using different funding modalities, depending on the amount of earmarking they require and the extent to which they rely on government systems for planning, disbursement and monitoring of funds. These include project, programme aid, sector wide approaches and budget support, with projects having the most earmarking and budget support the least (Foster and Leavy 2001). See Section 2 for a discussion of aid modalities.

Concerns about the efficacy and effectiveness of development assistance are not new and have resulted in several international declarations endorsing 'good practice' principles aimed at improving aid effectiveness, including the Monterrey Consensus on Financing for Development in 2002, the Rome Declaration on Harmonization in 2003 and the Joint Marrakech Memorandum on Managing for Results. 
Table 1: Development assistance for health flows (2009 constant US\$ millions)

\begin{tabular}{|c|c|c|c|c|c|c|c|c|c|c|c|c|c|c|}
\hline Year & $\begin{array}{l}\text { Africa (non- } \\
\text { specified) }\end{array}$ & $\begin{array}{l}\text { America (non- } \\
\text { specified) }\end{array}$ & $\begin{array}{l}\text { Asia (non- } \\
\text { specified) }\end{array}$ & Europe & Far East Asia & Middle East & $\begin{array}{l}\text { North \& } \\
\text { Central } \\
\text { America }\end{array}$ & $\begin{array}{l}\text { North of } \\
\text { Sahara }\end{array}$ & Oceania & $\begin{array}{l}\text { South \& Central } \\
\text { Asia }\end{array}$ & South America & South of Sahara & Unspecified & Grand Total \\
\hline 1973 & & & & 19.49618124 & 99.09566662 & & 0.224883675 & 86.45212557 & 7.31569032 & 19.27003169 & 212.8359661 & 157.1627558 & & 601.853301 \\
\hline 1974 & & & & & 88.82041736 & 0.218576842 & 94.21013857 & 6.833660202 & 11.58165584 & 67.76448141 & 85.1858849 & 232.3985212 & & 587.0133364 \\
\hline 1975 & & & & & 22.16357456 & 5.820907485 & 139.7931362 & & 11.28823437 & 244.7256012 & 23.66324801 & 113.2291298 & 0.334288516 & 561.0181201 \\
\hline 1976 & 0.185255234 & & & 0.797308746 & 82.94963823 & 1.46886642 & 272.6727707 & 45.28607588 & 17.09836561 & 65.56233124 & 67.40752577 & 127.7409597 & & 681.1690975 \\
\hline 1977 & & & & 1.683612553 & 56.34726082 & 28.24052027 & 32.50201807 & 19.46373256 & 13.41630898 & 190.4349687 & 13.91713511 & 165.8500812 & & 521.8556382 \\
\hline 1978 & 0.64424937 & 2.407134489 & & & 304.9456878 & 9.619513637 & 106.8552672 & 70.69806449 & 14.05097418 & 166.6985811 & 117.3475973 & 172.9945688 & & 966.2616383 \\
\hline 1979 & & & & 0.656009348 & 282.1369811 & 1.043703107 & 13.11640587 & 26.3156607 & 2.303883385 & 195.6303932 & 77.46865771 & 160.8694557 & & 759.5411501 \\
\hline 1980 & & & & 0.220564825 & 215.0893301 & 5.96849822 & 130.8539787 & 129.5146723 & 1.133146624 & 418.8830741 & 65.0447117 & 170.4085443 & 0.831600417 & 1137.948121 \\
\hline 1981 & 23.72775573 & 0.561410674 & 3.274241392 & & 343.8508778 & 1.643417314 & 190.9883859 & 178.3422077 & 4.186935329 & 389.7997009 & 92.49871885 & 337.5526393 & 21.61191989 & 1588.038211 \\
\hline 1982 & 36.70946899 & 1.016795121 & 1.972266023 & & 295.4943745 & 33.45537484 & 149.9040715 & 92.35166283 & 2.143727253 & 275.4197726 & 166.534109 & 517.537324 & 9.907532937 & 1582.44648 \\
\hline 1983 & 43.40458006 & 1.672416269 & 5.848357826 & 0.146689821 & 194.3253649 & 49.09825335 & 88.03043469 & 90.24167459 & 8.665171139 & 367.5543838 & 100.9937196 & 455.3169493 & 25.63260323 & 1430.930598 \\
\hline 1984 & 38.30078099 & 0.341132947 & 10.4192989 & & 369.7263166 & 70.06226917 & 93.04281003 & 25.40165552 & 12.46461285 & 613.1957146 & 135.8226601 & 383.6588151 & 31.12587668 & 1783.561943 \\
\hline 1985 & 49.57091594 & 5.153573279 & 11.51282964 & & 262.9445092 & 38.43715391 & 243.4221234 & 99.96144241 & 60.54215798 & 501.0997819 & 96.62394804 & 538.6044055 & 19.13791908 & 1927.01076 \\
\hline 1986 & 45.61528242 & 19.74073163 & 16.43205202 & & 150.028725 & 27.26953315 & 198.5645749 & 77.42756903 & 25.36959723 & 661.0881285 & 40.90386525 & 560.6046753 & 36.38635574 & 1859.43109 \\
\hline 1987 & 86.25503584 & 5.131764224 & 9.130717893 & 12.70385789 & 253.7941038 & 26.28985006 & 266.6659099 & 84.85236219 & 14.57758588 & 450.9709619 & 69.96222605 & 699.6512452 & 45.28452494 & 2025.270146 \\
\hline 1988 & 151.0943332 & 25.72323125 & 6.610118796 & 3.474178205 & 185.0122078 & 19.47655811 & 182.433026 & 189.7367565 & 20.81628327 & 467.192683 & 155.5220581 & 1018.128238 & 131.3011133 & 2556.520786 \\
\hline 1989 & 118.1543848 & 11.22204105 & & 0.175825347 & 236.477793 & 23.8114055 & 204.7960558 & 78.04519964 & 32.50218388 & 533.3964754 & 112.5014853 & 921.1126746 & 114.0111471 & 2386.206671 \\
\hline 1990 & 61.05424184 & 6.900219148 & 5.760949909 & & 318.6135082 & 17.84398583 & 180.7909335 & 31.85183698 & 37.21699946 & 775.1818979 & 130.0766592 & 887.208564 & 29.49459915 & 2481.994395 \\
\hline 1991 & 116.1217346 & 2.864988749 & 7.468618557 & 0.691127457 & 317.9888423 & 64.10963183 & 192.4856672 & 74.53718663 & 75.4050643 & 681.0682667 & 175.0132787 & 1128.498768 & 63.52189442 & 2899.775069 \\
\hline 1992 & 41.98112471 & 2.491130521 & 6.567949316 & 33.47311336 & 117.6393361 & 21.91256822 & 177.6068949 & 122.6479086 & 49.14549442 & 1109.875167 & 181.0898923 & 1176.568002 & 142.696812 & 3183.695393 \\
\hline
\end{tabular}




\begin{tabular}{|c|c|c|c|c|c|c|c|c|c|c|c|c|c|c|}
\hline 1993 & 26.47668252 & & 4.189576967 & 2.10677583 & 658.2643838 & 87.57190556 & 297.89413 & 148.9527058 & 44.30314551 & 552.0848201 & 199.9856795 & 1166.24185 & 253.0334743 & 3441.105129 \\
\hline 1994 & 69.88280702 & 0.021327116 & 3.457786711 & 31.33195046 & 385.8234545 & 50.19230698 & 141.4072371 & 115.7409639 & 34.74439055 & 1029.741309 & 137.9220842 & 1088.202962 & 740.2835278 & 3828.752107 \\
\hline 1995 & 39.70945512 & 2.347773389 & 1.076049237 & 40.21565817 & 446.9439108 & 80.54901454 & 238.8550051 & 130.1487862 & 8.391671703 & 406.932973 & 300.065659 & 1381.407387 & 845.0651599 & 3921.708503 \\
\hline 1996 & 47.01138919 & 3.878246699 & 2.377169733 & 45.32448539 & 728.3707097 & 83.52769031 & 249.8788306 & 79.47585121 & 82.99346758 & 1162.385648 & 123.9831447 & 1174.461465 & 467.9699887 & 4251.638087 \\
\hline 1997 & 94.10113241 & 41.94251181 & 54.23891852 & 55.28475789 & 329.7822297 & 54.89582616 & 279.8529643 & 59.83357953 & 55.81654336 & 1446.655852 & 255.1929963 & 1272.530341 & 567.6754737 & 4567.803126 \\
\hline 1998 & 51.30337345 & 16.46345326 & 19.39075532 & 64.99931609 & 469.5838767 & 89.34071089 & 433.5516426 & 455.3025303 & 76.01717453 & 1561.667063 & 211.0861327 & 1622.407016 & 586.2108839 & 5657.323928 \\
\hline 1999 & 91.36473544 & 13.97389845 & 30.21191096 & 129.5222975 & 571.3185059 & 97.21006292 & 332.88719 & 152.9182551 & 147.2913747 & 832.2528149 & 313.6423953 & 1734.016945 & 614.2476208 & 5060.858007 \\
\hline 2000 & 122.2966317 & 21.8745737 & 29.56580329 & 228.2127936 & 570.3159148 & 145.1818712 & 214.0607453 & 202.8628406 & 205.909608 & 1314.157179 & 198.648662 & 2707.311943 & 596.4864843 & 6556.88505 \\
\hline 2001 & 78.35436128 & 38.55702649 & 34.92323908 & 82.42543579 & 713.7963168 & 115.8466706 & 267.0792706 & 114.2183161 & 101.1764853 & 792.2695059 & 251.3471443 & 2881.298785 & 930.2545101 & 6401.547067 \\
\hline 2002 & 73.00076346 & 28.75589583 & 68.58262614 & 112.7643773 & 818.5022685 & 249.643004 & 424.8545476 & 106.4480679 & 137.0596077 & 1025.274809 & 247.6124065 & 3147.858946 & 1508.263458 & 7948.620779 \\
\hline 2003 & 125.7008984 & 16.60087488 & 36.9511949 & 186.7975106 & 982.366066 & 228.9164228 & 370.2401227 & 98.84183708 & 125.2296951 & 1397.21378 & 357.9395983 & 4041.083241 & 1776.675985 & 9744.557227 \\
\hline 2004 & 803.0569352 & 522.0791525 & 336.3560142 & 4633.411447 & 11945.3586 & 13566.48616 & 4898.820409 & 4281.15107 & 1452.810176 & 17891.25914 & 4685.382864 & 34888.09703 & 15113.81615 & 115018.0851 \\
\hline 2005 & 583.4397282 & 525.9642569 & 881.7921555 & 6627.64663 & 14399.36678 & 25924.44902 & 5587.403291 & 3479.319614 & 1307.561031 & 19338.03315 & 3933.329389 & 43478.56035 & 14559.71106 & 140626.5765 \\
\hline 2006 & 48.90396041 & 19.46542205 & 19.08829623 & 199.6676687 & 1225.346277 & 447.7125212 & 466.2802792 & 217.8485907 & 155.3642153 & 3155.973204 & 257.3045151 & 6050.547723 & 3178.26001 & 15441.76268 \\
\hline 2007 & 209.7076477 & 48.10007203 & 70.352063 & 183.9678724 & 1148.472301 & 299.8163644 & 438.818928 & 218.2165315 & 116.0177964 & 2799.027106 & 288.9828523 & 7570.435107 & 3333.847031 & 16725.76167 \\
\hline 2008 & 122.6016923 & 49.29439215 & 82.00519215 & 285.6391601 & 1312.414283 & 369.8554684 & 478.4763388 & 243.1542854 & 206.0053196 & 2220.96943 & 312.7120835 & 8853.899668 & 3043.574955 & 17580.60227 \\
\hline 2009 & 87.39993038 & 169.7937733 & 195.1448603 & 263.7147833 & 1502.733271 & 295.3387056 & 597.2671315 & 288.8558004 & 172.6528812 & 1807.676339 & 399.833272 & 9962.099381 & 4213.150444 & 19955.66057 \\
\hline 2010 & 172.3375214 & 135.4383654 & 96.96826942 & 360.3804622 & 1333.468512 & 333.8217602 & 606.3909644 & 134.5220091 & 220.0949605 & 2276.666525 & 276.3407893 & 9364.452268 & 3974.507305 & 19285.38971 \\
\hline
\end{tabular}

Source: based on OECD-CRS data. 
The most important declaration so far has been the Paris Declaration on Aid Effectiveness in 2005, where donors, recipient countries and multilaterals agreed on five principles of 'good practice': ownership, alignment, harmonization, mutual accountability and results-based management. The mid-term evaluation found that although some progress was being made, it was not fast enough (OECD 2008b), which lead to the signing of the Accra Agenda for Action in 2008, to accelerate progress towards ownership, inclusive partnerships and results. The deadline of the Paris Declaration is now up, and its evaluation found that overall the quality of aid has improved, but highlights lack of transparency and aid management burden as impeding progress. Importantly, it calls for more realistic expectations of the contribution of aid to development (Wood et al. 2011).

The Paris Declaration was followed by the Fourth High-Level Forum on Aid Effectiveness, which took place in Busan in November 2011. The principles for best practice agreed are not too dissimilar from previous declarations with partners committing to ownership of development priorities by developing countries, focus on results, inclusive development partnerships and transparency and accountability to each other. By the middle of 2012 a set of indicators will be developed to monitor progress towards these principles.

It is therefore important to assess what we know about the effectiveness of development assistance for health, successes, failures and what has worked in making aid more effective. After this introduction this paper will cover methodological challenges in assessing the effectiveness of development assistance for health, followed by a review of the current evidence on whether aid works. Section 3 will then outline the different aid modalities, examples of their successes and lessons learnt. This is followed by an overview of the factors hindering the effectiveness of DAH in Section 4. Section 5 will then highlight the issues associated with scaling up aid-funded health programmes. The paper will finish with a discussion summarizing key issues in the current debate on aid effectiveness and with a look at the future of development assistance for health, including new donors and partnerships, shifting donor priorities and the effect of the financial crisis on DAH.

\section{Methodological challenges in assessing aid effectiveness}

How can we study the impact of aid? One obvious way is to examine welfare benefits that can be attributed of aid funding to the recipient countries. In the early literature around growth and development, which emphasised rapid capital investment and emerged in the 1950s after many low- and middle-income countries gained independence, it was argued that aid would make up the shortfall in foreign reserves and domestic savings that many countries consistently faced (Chenery and Strout 1966). It was also recognized that there would be humanitarian aid. Further, the geopolitical landscape of the Cold War ensured that foreign aid would flow to poorer countries which would not have expressed developmental concerns (Bourguignon and Leipziger 2006; Bobba and Powell 2007). Although aid sceptics voiced strong views, particularly the British economist P.T. Bauer in the 1970s, a strong body of literature only emerged nearly ten years after the Cold War when aid giving was expressly meant for raising the level of wellbeing in LMICs (see bibliography in (Rajan and Subramanian 2008). Controversies around aid effectiveness centred on bilateral aid; multilateral aid seemed to have generated very little controversy. For example, Headey (2007) argues that multilateral aid for 56 countries for years 1970-2001, which may have had less political intent, has had a positive effect. We did not find much of analysis that centred on 
ineffectiveness of multi-lateral aid; we note below that responsiveness to, for example, concessionary loans seems to be positive.

In answering questions around aid effectiveness, the primary concern has been growth. Given the recent emphasis on development assistance for health and aid aimed specifically at particular development aims, questions around effectiveness of particular type of funding have also emerged. Concerns about the process of aid-giving have also been raised. A question around process involves domestic fiscal response to aid; another involves questions around modality of offering aid. The last two questions lead to qualitative issues around accountability. The issues can be summarized into three categories: (1) welfare implication of aid; (2) fiscal response to aid; and (3) modality of aid. In this section we examine some methodological issues that pertain to examining aid effectiveness, whether it be overall aid effectiveness or sector specific effectiveness.

\subsection{Aid benefits}

Questions as to whether aid benefits recipient countries or not is methodologically confounded by endogeneity problems, including reverse causality. This problem is beyond just being a methodological issue. In recent years we note the phenomenon of being a 'donor darling' when certain countries have, starting from a surge, a large number of donors along with large per capita development assistance. The surge follows the recipient country experiencing sudden economic upturn or a period of peaceful recovery from conflict. Cassen (Cassen 1986) noted the tendency for aid to follow well-performing countries. Although this may indicate that donor countries would like to see their aid work and claim credit for good performing countries, it also makes it difficult to measure the impact of aid. Thus, it is possible we will find that aid follows good performance while lack of aid follows bad performance. Further, if aid improves some type of performance around education, health or economic growth, we should not expect the impact to be completely instantaneous but to have a lagged effect. As Rajan and Subramanian (2005) put it we want to know: can aid take a country to its potential, a higher rate of consistent economic growth rate? This entails that longer horizons be examined whenever impact of aid is studied (Rajan and Subramanian 2005), which would necessitate longer run analysis. An important way of seeing if the potentials are met is to examine if aid affects intermediary factors such as human capital, health and investment, as has been done by Arndt et al. (2011).

What constitutes 'longer run' would be a natural and empirical question to ask. Should this be a time when the current aid recipient countries started receiving aid? If so, the postindependence period of 1960 to today should be the examination period. This may be an interesting period but the purpose and mode of aid giving has dramatically changed since the 1960s. In 1960 a developing country on average received aid from two countries, while the corresponding number was 28 in 2008 (Frot and Santiso 2008). Also in this period, many of the larger recipients were given aid for political reasons, thus it is common to single out countries such as Egypt (Rajan and Subramanian 2005) and adjust for countries where motivations for aid may be political and not socioeconomic development. This adjustment does not solve the problem of endogeneity, even in a panel data with fixed effect, as one might notice, for example, the problem of 'aid darlings' might arise and disappear within the period of analysis. The use of fixed country effect, structural model or generalized method of moments with instrumentation for aid giving to isolate the exogenous element of aid giving go some ways to correct for some of these problems. A host of instrumentations have been 
used to find exclusion condition which cannot be related to economic performance (see (Rajan and Subramanian 2008; Hansen and Tarp 2000; Arndt et al. 2011), among others). Testing for exogeneity in time series, (Juselius et al. 2011) find aid is not usually exogenous. Most likely, the choice of the years included in the study will matter, as years since the Cold War may have had more economic interest attached to aid giving. One way of avoiding making a choice is to report on different divisions of 1960 to the present with some time effect. Another natural division is to report on impact of aid since the end of Cold War (Lu et al. 2010). The shorter period ignores the cumulative and the long-term effect of aid (Arndt et al. 2011).

Rajan and Subramaniam (2005) along with many others concluded that total development assistance did not result in higher growth rate, see (Doucouliagos and Paldam 2011). The opposite has also been shown. Arndt et al. (2011) show a positive impact on growth through a structural model where life-expectancy along with investment and education are intermediary factors through which aid affects growth. An interesting tact is to examine effectiveness at the country level as done by (Dollar and Easterly 1999), finding aid ineffectiveness in general, and Juselius et al. (2011), finding aid effectiveness in general. Few studies have measured the impact of development assistance on health. As something like DAH may lack apparent political motivations and be expressly aimed toward improving wellbeing, some authors have tried to measure the impact of developmental aid setting aside nondevelopmental aid such as military aid. Clemens et al. (2004) indicated that for the short run aid allocated to support budget and balance of payments commitments and infrastructure result in rising income. Similarly they speculate that aid promoting democracy, health and education will have a long-run impact on growth. Minoiu and Reddy (2010) show through Gaussian mixture model (GMM) estimation that when total is separated into developmental and non-developmental aid, non-developmental aid does not contribute to growth while developmental aid's contribution to growth is strong.

Examining the link between development assistance meant for the purpose of development goes some way toward seeing if DAH is effective. But it is not a direct method of measuring the impact. A question can be how much donor expenditure targeted as DAH contributes toward development. Mishra and Newhouse (2007) present some interesting discussions regarding inferring links between donor expenditure and developmental indicators. First, one might think lagged values of aid might be predictor of current development indicator along with country fixed effects; however, as indicated before, country fixed effects do not take account of country-specific factors that are time variant and may be related to health and DAH. Donors may respond to previous health system crises for example. Mishra and Newhouse estimate system GMM method for data from 1975 to 2004 to obtain a result that shows doubling health aid decreases infant mortality by 2 per cent in a subsequent five-year period. Obviously regression methods show marginal changes; thus a slightly ambitious interpretation the authors give is that DAH may have saved 170,000 lives at the costs of US\$76 million (\$432/life) (Mishra and Newhouse 2007). This is corroborated by Burnside and Dollar (1999), who find that for countries with effective public management, aid reduces infant mortality - they find that aid equivalent to 1 per cent of GDP reduces child mortality by 0.9 per cent. But on the other hand, Wilson (2011), using data from 96 high-mortality countries found that DAH has no effect on mortality and its effectiveness has not improved over time. Finally, the paper by Masanja et al. (2008) on Tanzania links drops of 24 per cent of child mortality with doubled expenditure on health, decentralization policies, the sectorwide approach (SWAP) and vertical programmes to prevent malaria and improve nutrition. 
The discussions around relevant time periods for analysis draw attention to how aid was seen from the point of donors. After the Cold War donors tended to express concerns over specific developmental aims, for example improved health. A question one can raise is: how do recipients view aid when it is specifically designated for a particular sector? This issue revolves around how DAH would be seen by the recipient country. Recipient governments would see DAH simply as income, although they might constrain themselves to spending at least the DAH amount, and adjust their expenditure accordingly.

\subsection{Fiscal spending and foreign aid}

When isolating the impact of DAH it is often asked whether it is legitimate to expect that the recipient sees the budget provided for health or development is as solely for the purpose of additional amount of expenditure on health. Thus US\$100 million for health yields a health budget US\$100 million above what the recipient would have planned on spending. This is known as the issue of fungibility. If donors earmark aid by specifying it as DAH then they expect recipient public expenditure on health should rise by exactly that much from the level planned. It is, of course, very difficult to observe what was planned. We take up the measurability issue around fungibility.

Questions around fungibility stem from the literature known as the flypaper effect which is observed for public financing under fiscal federalism (Hines and Thaler 1995). Empirical findings indicate that money given to states in the USA by the federal government is actually spent rather than replacing state-level revenue. Of course, extra funding should result in some expenditure increase due to income effect, but the observation has been that funding induces expenditure beyond what would be predicted by income effect. The stickiness of the flypaper is perhaps what motivates earmarked funding in the international setting. Economic theory goes against the view that federal allocation earmarked for particular activities should be seen anything other than the regular income generated by the states, say, through income tax. As van de Walle and Mu (2007) point out economists would find fungibility as the norm. However, in international policy circles the expectation is for there to be no fungibility; the donor community would expect no decline in domestic expenditure when aid budget is increased for a particular sector. As any measure of fungibility requires that a counterfactual be known, a simpler question is, all things being equal, if a country receives US\$1 extra in health aid in comparison to another country, does that lead to US\$1 increase in public expenditure on health? The question is whether or not aid funding to government results in exactly the same amount of government expenditure. Feyzioglu et al. (1996) report that US\$1 increase in bilateral foreign aid induces much less than US\$1 rise in government expenditure; the corresponding increase seems to be much higher than induced by concessionary loans received from multi-lateral donors.

There is even the expectation of additionality; there should be some matching of increasing in domestic allocation as donor funding for a sector is increased (Brown et al. 2006). Conceptually, additionality may be easier to detect for a new programme, for example an HIV/AIDS programme, and this is where this concept has been emphasized. As donor countries put in more money, the same amount of money must be committed by the recipient from a point of zero funding. Fungibility is slightly different, as there is an expectation of some type of optimal behavior. It is easier to ask as stated before: does the total sectoral government expenditure, financed from resources made up of domestic revenue and foreign 
aid targeted to the sector, increase exactly by the amount of targeted developmental aid? 1 Usually the test has been to detect whether or not the coefficient for the relation between the public domestic sectoral expenditure and earmarked funding is near to unity in some type of regression. The meaning of the coefficient is not exactly clear in welfare terms.

As noted above, foreign aid was often thought of in terms of filling a gap-perhaps one can think of development assistance as complimenting recipients' domestic efforts. In this view one would note low levels of domestic expenditure on health, say, and this low level would be supplemented by donor funding earmarked for health to have a total amount not too much beyond the $\mathrm{DAH}$. In recent years, the notion that fungibiltiy should be prevented entails that country do not see DAH merely as an income for the overall budget; the expenditure on the earmarked sector would be beyond what would be predicted by income effect (van de Walle and Mu 2007).

In examining the relation between DAH and domestic expenditure the usual issues around endogeneity apply. As already stated, the empirical work is not exactly testing fungibility which embeds a counterfactual concept; however, we will use the word 'fungibility' below as shorthand. There is also a plethora of number of indicators used as dependent variables to reflect fiscal commitment, such as public expenditure per capita or public expenditure as a ratio of GDP.

\subsection{Modality of aid-giving}

The way in which aid is distributed may have different implications. Modalities can consist of giving direct aid within the budgetary process in the recipient country, carrying out specific projects through governmental channels, or directly funding projects through the private sector-private providers and NGOs to provide goods at subsidised rate. Discerning these channels from existing datasets has been difficult. Lu et al. (2010) suggest, using their own imputated data as to what might be funded through the non-governmental sector in the Organization for Economic Co-operation and Development (OECD) data on foreign assistance, that donor contribution through private means induces governments to increase their expenditure at a higher rate.

Another concern has been that aid is provided through multiple transfer instances and there are multiple donors for a single country as indicated above. Multiple events induce bureaucratic pressures. The presence of multiple donors induces unexpected impacts. Standard measures of concentration of donor activities using indices similar to the Herfindahl index of monopoly power indicates that fragmented aid giving is large (Acharya et al. 2006). The implications of fragmentation are debatable. Easterly (2002) claims donors can act as a de facto cartel in dictating what is done with the funding, hence the fact that the modality of funding dispersment does not matter. Knack and Rehman (2007) argue that it is unlikely a donor will internalize utilities of success and failure of other donors in a given country as the number of donors is large. There is diffused responsibility if the number of donors increases. Development assistance for health has become a favourite type of aid, as we note below. Thus the question of fragmentation is not inconsequential with regards to health. We also note below that multiple aid events, which may be more prevalent when non-government channels are used to deliver health, may impose a great deal of bureaucratic burden.

1 Pack and Pack (1993); Boone (1996); Feyzioglu et al. (1998). 
Despite the methodological difficulties highlighted in Section 2, the literature assessing the effectiveness of aid, and DAH in particular, is growing. As outlined in the introduction, donors disburse funding using different modalities, depending on the degree of earmarking and trust in country systems. This section will summarize the current knowledge on the different aid modalities, and highlight successes and what can be learnt from them

\subsection{Project aid}

Project aid is the most earmarked type of aid. Projects are discrete interventions usually delivered through parallel systems, bypassing the government, where donors have control over the design, monitoring, disbursement and accountability procedures, and NGOs or the private sector are in charge of implementation (Foster and Leavy 2001). Projects are also sometimes delivered using government systems, where donors control the policy conditions and the sector in which the project is situated, but the funds are disbursed and accounted for using government systems. Projects have been criticised for lacking sustainability (Leader and Colenso 2005), having high transaction costs (Quartey 2005; NORAD 2008) and hindering partner country ownership (Marshall and Ofei-Aboagye 2004).

An analysis of projects financed by the World Bank throughout the years 1983-2009 (Denizer et al. 2011) found that the success of projects was correlated with overall country performance. In addition, it highlighted that the true impact of projects only becomes apparent over time and later evaluations tend to be less optimistic. This is particularly the case in the health sector, where the impact of interventions takes time to be seen. The evaluation found that some factors, such as high preparation costs and low country ownership, were associated with lower impact of projects. On the other hand, smaller size, good management and supervision were correlated with a higher impact of projects. However, the authors of the analysis (Denizer et al. 2011) do acknowledge that a significant proportion of the variation observed in project performance cannot be explained by these factors, highlighting the importance of the local context on project outcomes. A series of case studies conducted by the What Works Group at the Center for Global Development found that a World Bank funded project in China averted 30,000 cases of tuberculosis per year. The project's success was associated with high levels of political commitment at all levels of government and the use of creative incentives to both patients and providers (Levine 2004). Table 2 below summarizes other studies of successful projects.

Despite their criticism, projects can be effective in achieving their objectives. However, concerns regarding sustainability and weakening of country systems have driven the international community to favour programme-based approaches, such as SWAPs and budget support. This shift was at the heart of the Paris Declaration in 2005 and is still being pursued by many donors. 
Table 2: Development assistance for health projects

\begin{tabular}{|c|c|c|c|c|c|c|c|c|c|c|c|}
\hline Author(s) & Title & $\begin{array}{l}\text { Year of } \\
\text { publication }\end{array}$ & Year of study & $\begin{array}{l}\text { Type of } \\
\text { Publication }\end{array}$ & $\begin{array}{l}\text { Type of policy } \\
\text { intervention } \\
\text { under analysis }\end{array}$ & Country/Region & Rura/Urban & $\begin{array}{l}\text { Methodology } \\
\text { used } \\
\text { (experimental - } \\
\text { what type of } \\
\text { experimental } \\
\text { design; non- and } \\
\text { quasi- } \\
\text { experimental } \\
\text { approaches) }\end{array}$ & Sample size & $\begin{array}{l}\text { Outcome } \\
\text { variables used }\end{array}$ & Main findings (and shortcomings) \\
\hline $\begin{array}{l}\text { Denizer, C., } \\
\text { Kaufmann, D. } \\
\text { \& Kraay, A. }\end{array}$ & $\begin{array}{l}\text { Good Countries } \\
\text { or Good } \\
\text { Projects? } \\
\text { Macro and Micro } \\
\text { Correlates of } \\
\text { World Bank } \\
\text { Project } \\
\text { Performance }\end{array}$ & 2011 & Unspecified & Working paper & Project & World & Both & $\begin{array}{l}\text { Non- } \\
\text { experimental } \\
\text { (regression } \\
\text { analysis of } \\
\text { World Bank } \\
\text { data) }\end{array}$ & 6,253 projects & $\begin{array}{l}\text { Whether project } \\
\text { has met its } \\
\text { development } \\
\text { objective }\end{array}$ & $\begin{array}{l}\text { The study found that the success of projects was } \\
\text { correlated with overall country performance. In } \\
\text { addition, it highlighted that the true impact of } \\
\text { projects only becomes apparent over time and later } \\
\text { evaluations tend to be less optimistic. This is } \\
\text { particularly the case in the health sector, where the } \\
\text { impact of interventions takes time to be seen. The } \\
\text { evaluation found that some factors, such as high } \\
\text { preparation costs and low country onnership, were } \\
\text { associated with lower impact of projects. On the } \\
\text { other hand, smaller size, good management and } \\
\text { supervision were correlated with a higher impact of } \\
\text { projects. The authors acknowledge that a significant } \\
\text { proportion of the variation observed in project } \\
\text { performance cannot be explained by these factors. }\end{array}$ \\
\hline Munishi, G. K. & $\begin{array}{l}\text { Intervening to } \\
\text { address } \\
\text { constraints } \\
\text { through health } \\
\text { sector reforms in } \\
\text { Tanzania: some } \\
\text { gains and the } \\
\text { unfinished } \\
\text { business }\end{array}$ & 2003 & Unspecified & Journal article & $\begin{array}{l}\text { Urban health } \\
\text { project }\end{array}$ & Tanzania & Urban & $\begin{array}{l}\text { Non- } \\
\text { experimental, } \\
\text { case study } \\
\text { design }\end{array}$ & Unspecified & $\begin{array}{l}\text { Rehabilitation of } \\
\text { Dar es Salaam's } \\
\text { health services } \\
\text { facilities. } \\
\text { Improved } \\
\text { system capacity } \\
\text { to deliver health } \\
\text { serices. } \\
\text { Implementation } \\
\text { of government's } \\
\text { decentralization } \\
\text { reforms }\end{array}$ & $\begin{array}{l}\text { The Dar es Salaam Urban Health Project } \\
\text { succeeded in creating an organized heatth system, } \\
\text { introducing the minimum health services package, } \\
\text { strengthening monitoring and evaluation and } \\
\text { improving community participation. Key in achieving } \\
\text { this was the sequencing of activities, where } \\
\text { structural quality was addressed before } \\
\text { implementing other activities, such as the provision } \\
\text { of drugs. Despite these achievements, the study } \\
\text { highlights the lack of political support and the } \\
\text { reliance on donor funding as concerns, particularly } \\
\text { with respect to project sustainability. }\end{array}$ \\
\hline
\end{tabular}




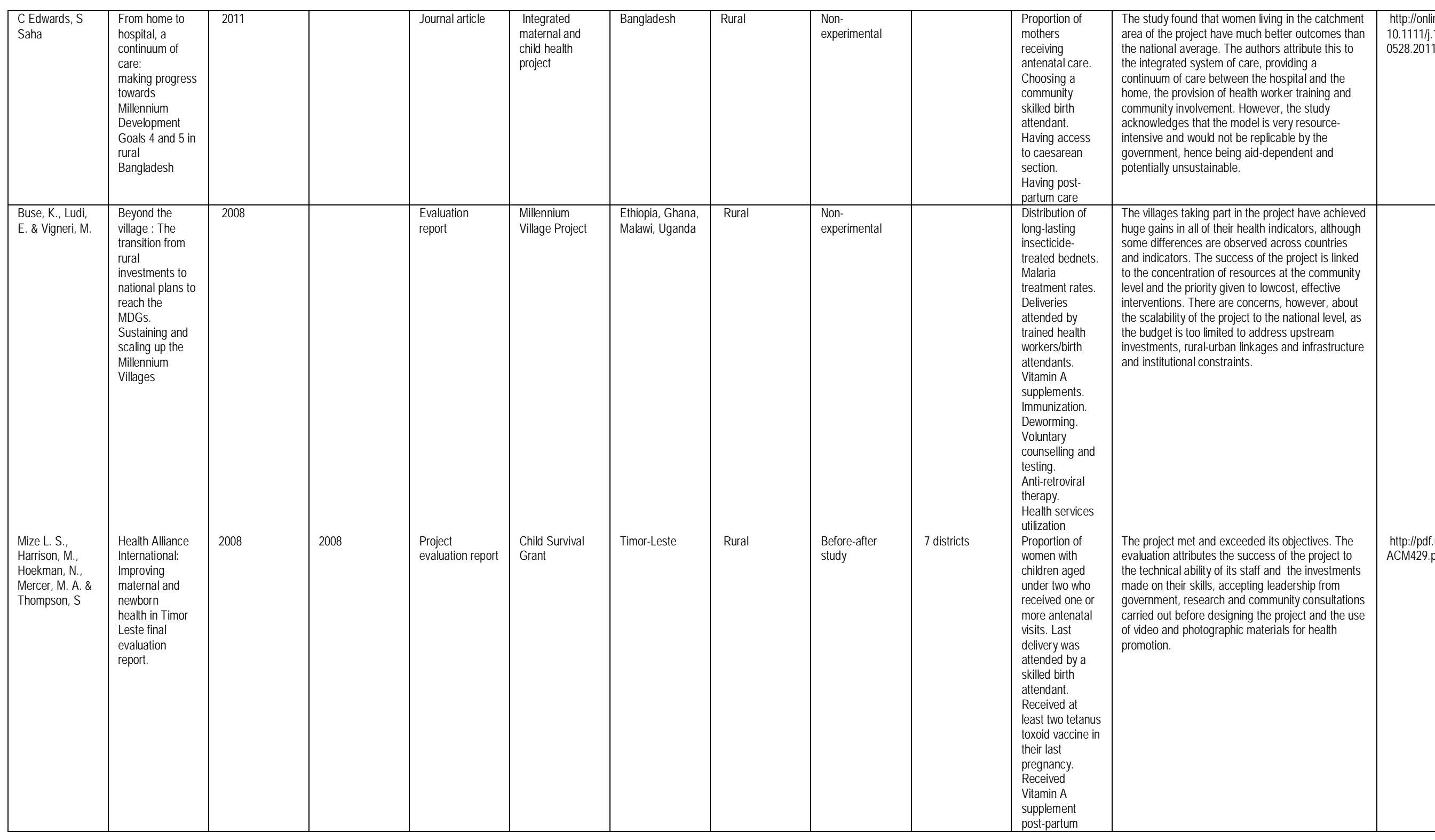




\begin{tabular}{|c|c|c|c|c|c|c|c|c|c|c|c|c|}
\hline & & & & & & & & & & $\begin{array}{l}\text { Exclusively } \\
\text { breastfed in the } \\
\text { first months }\end{array}$ & & \\
\hline $\begin{array}{l}\text { Hounton, S., } \\
\text { Menten, J., } \\
\text { Ouédraogo, M., } \\
\text { Dubourg, D., } \\
\text { Meda, N., } \\
\text { Ronsmans, C., } \\
\text { Byass, P. \& De } \\
\text { Browere, V. }\end{array}$ & $\begin{array}{l}\text { Effects of a } \\
\text { skilled care } \\
\text { ilinititivie on } \\
\text { pregnancy- } \\
\text { related mortality } \\
\text { in rural Burkina } \\
\text { Faso. }\end{array}$ & 2009 & 2006 & Journal article & $\begin{array}{l}\text { Shilled Care } \\
\text { Innitiative }\end{array}$ & Burkina Faso & Rural & $\begin{array}{l}\text { Quasi- } \\
\text { experimental }\end{array}$ & 2 districts & $\begin{array}{l}\text { Pregnancy } \\
\text { related mortality. } \\
\text { Utilization of } \\
\text { maternal health } \\
\text { senices }\end{array}$ & $\begin{array}{l}\text { The study found that the Skilled Care Initiative } \\
\text { project increased the number of babies delivered at } \\
\text { heath facilities (the aim of the project); however, it } \\
\text { had no effect on pregnancy relaled mortality. The } \\
\text { authors also found a low rate of caesarean } \\
\text { sections, which hhey intererret to mean that } \\
\text { sulbstantial barriers still exist to service delivery, } \\
\text { which may explain the lack of impact on heath } \\
\text { outcomes. }\end{array}$ & $\begin{array}{l}\text { hitp:///4mm } \\
\text { med/1857? }\end{array}$ \\
\hline
\end{tabular}

Source: authors' illustration. 


\subsection{Programme-based approaches}

Programme-based approaches (PBAs) are defined by the OECD as having the following characteristics:

1. being lead by the partner country;

2. having a single, comprehensive programme and budget framework;

3. donor co-ordination and harmonization of donor procedures for budgeting, management, procurement and reporting;

4. increased use of partner country systems (OECD 2008a).

They encompass basket funding, SWAPs, and budget support. They also include project aid that is delivered as part of a SWAP or pooled through a basket fund. Driven by the discontent with traditional project aid, donors committed to giving two-thirds of their aid in the form of PBAs by 2010 at the Paris Declaration on Aid Effectiveness in 2005. However, the mid-term evaluation found that the proportion of aid delivered as PBAs had only increased from 43 per cent in 2005 to 47 per cent in 2007 (OECD 2008a). The final evaluation of the Paris Declaration found that with a few exceptions, such as Uganda, there had been no rapid or linear move towards PBAs, with most of the evaluated countries and donors delivering aid using mixed modalities. In fact, it found a general reluctance on the part of the donors to move towards these approaches, mainly due to the slow pace of public reforms, which contributed to high fragmentation of aid. However, it also found that although PBAs require more effort than traditional project aid, they resulted in higher policy influence by the donors (for instance, in better targeting of expenditure on poorer communities), and better understanding of performance-based approaches by the partner governments, which lead the evaluators to reinforce the suitability of PBAs as the core target of the Paris Declaration, and to recommend it be included in further declarations and policy discussions (Wood et al. 2011). Examples of PBAs are shown in Table 3. SWAPs and budget support are discussed below. 
Table 3: Programme-based approaches

\begin{tabular}{|c|c|c|c|c|c|c|c|c|c|c|c|}
\hline Author(s) & Title & $\begin{array}{l}\text { Year of } \\
\text { publication }\end{array}$ & Year of study & $\begin{array}{l}\text { Type of } \\
\text { Publication }\end{array}$ & $\begin{array}{l}\text { Type of policy } \\
\text { intervention } \\
\text { under analysis }\end{array}$ & $\begin{array}{l}\text { Country/ } \\
\text { Region }\end{array}$ & $\begin{array}{l}\text { Methodology } \\
\text { used }\end{array}$ & Sample size & $\begin{array}{l}\text { Outcome } \\
\text { variables used }\end{array}$ & Main findings (and shortcomings) & web link (URL) \\
\hline $\begin{array}{l}\text { Chansa, C. } \\
\text { Sundewall, J. } \\
\text { McIntyre, D. } \\
\text { Tomson, G. } \\
\text { Forsberg, B. } \\
\text { C. }\end{array}$ & $\begin{array}{l}\text { Exploring } \\
\text { SWAP } \\
\text { contribution to } \\
\text { the efficient } \\
\text { allocation and } \\
\text { use of } \\
\text { resources in } \\
\text { the health sect } \\
\text { or in Zambia. }\end{array}$ & 2008 & $2005-2007$ & Journal article & SWAP & Zambia & $\begin{array}{l}\text { Non- } \\
\text { experimental, } \\
\text { case study } \\
\text { approach }\end{array}$ & $\begin{array}{l}26 \\
\text { stakeholders } \\
\text { (21 in-depth } \\
\text { interviews and } \\
\text { one group } \\
\text { interview) }\end{array}$ & $\begin{array}{l}\text { Administrative, } \\
\text { technical and } \\
\text { allocative } \\
\text { efficiency }\end{array}$ & $\begin{array}{l}\text { The SWAP was not found to have } \\
\text { achieved the expected improvements } \\
\text { in efficiency. The authors attribute } \\
\text { this to the partial implementation of } \\
\text { the SWAP or the fact that it had not } \\
\text { been embraced by all donors. } \\
\text { Although they do not classify the } \\
\text { SWAP approach as unsuccessful, the } \\
\text { authors find it ineffective in its current } \\
\text { form. }\end{array}$ & $\begin{array}{c}\text { http://heapol.o) } \\
\mathrm{nt/23/4/244.Iong}\end{array}$ \\
\hline Buse, K. & $\begin{array}{l}\text { Keeping a tight } \\
\text { grip on the } \\
\text { reins: donor } \\
\text { control over } \\
\text { aid } \\
\text { co-ordination } \\
\text { and } \\
\text { management } \\
\text { in Bangladesh } \\
\end{array}$ & 1999 & $1996-1997$ & Journal article & SWAP & Bangladesh & $\begin{array}{l}\text { Non- } \\
\text { experimental, } \\
\text { case study }\end{array}$ & $\begin{array}{l}\text { Discussions } \\
\text { with } 87 \\
\text { stakeholders } \\
\text { and } \\
22 \text { semi- } \\
\text { structured } \\
\text { questionnaires }\end{array}$ & $\begin{array}{l}\text { Effectiveness } \\
\text { of aid co-- } \\
\text { ordination } \\
\text { instruments }\end{array}$ & $\begin{array}{l}\text { The study found that the SWAP did } \\
\text { not succeed in allowing the } \\
\text { government to play a leading role in } \\
\text { aid management. This is in part due } \\
\text { to donors not trusting country } \\
\text { systems and in part because of the } \\
\text { politics and power associated with aid } \\
\text { co-ordination and particularly, with } \\
\text { having a leading role. }\end{array}$ & $\begin{array}{l}\text { http://heapol.oreall. } \\
\text { nt/14/3/219.full. }\end{array}$ \\
\hline $\begin{array}{l}\text { Bowie, C. } \\
\text { Mwase, T. }\end{array}$ & $\begin{array}{l}\text { Assessing the } \\
\text { use of an } \\
\text { essential } \\
\text { health package } \\
\text { in a sector } \\
\text { wide approach } \\
\text { in Malawi. }\end{array}$ & 2011 & 2008 & Journal article & SWAP & Malawi & $\begin{array}{l}\text { Cost- } \\
\text { effectiveness } \\
\text { analysis }\end{array}$ & $\begin{array}{l}55 \text { Essential } \\
\text { Health } \\
\text { Package } \\
\text { interventions }\end{array}$ & $\begin{array}{l}\text { Technical } \\
\text { efficiency, } \\
\text { defined as 'the } \\
\text { efficient } \\
\text { delivery of } \\
\text { health care to } \\
\text { a population, } \\
\text { through an } \\
\text { analysis of the } \\
\text { appropriatenes } \\
\text { s of the EHP } \\
\text { interventions } \\
\text { and their } \\
\text { coverage' }\end{array}$ & $\begin{array}{l}\text { This study found that the SWAP } \\
\text { invested in more cost-effective } \\
\text { interventions than donor } \\
\text { governments acting on their own. } \\
\text { This leads the authors to conclude } \\
\text { that the SWAP has resulted in an } \\
\text { improvement in health service } \\
\text { delivery at low cost. }\end{array}$ & $\begin{array}{l}\text { http://www.hea } \\
\text { systems.com/c } \\
\text { 9-4.pdf }\end{array}$ \\
\hline
\end{tabular}




\begin{tabular}{|c|c|c|c|c|c|c|c|c|c|c|c|}
\hline $\begin{array}{l}\text { Lister, S., } \\
\text { Carter, R. et al. }\end{array}$ & $\begin{array}{l}\text { Joint } \\
\text { Evaluation of } \\
\text { General } \\
\text { Budget } \\
\text { Support 1994- } \\
2004\end{array}$ & 2006 & 2005 & $\begin{array}{l}\text { Evaluation } \\
\text { report }\end{array}$ & $\begin{array}{l}\text { General } \\
\text { budget support } \\
\text { (GBS) }\end{array}$ & $\begin{array}{l}\text { Burkina Faso, } \\
\text { Malawi, } \\
\text { Mozambique } \\
\text { Nicaragua, } \\
\text { Rwanda, } \\
\text { Uganda, } \\
\text { Vietnam }\end{array}$ & $\begin{array}{l}\text { Non- } \\
\text { experimental, } \\
\text { case study } \\
\text { approach }\end{array}$ & $\begin{array}{l}7 \text { country case } \\
\text { studies }\end{array}$ & $\begin{array}{l}\text { GBS } \\
\text { relevancy, } \\
\text { efficiency and } \\
\text { effectiveness } \\
\text { in achieving a } \\
\text { sustainable } \\
\text { impact in } \\
\text { poverty } \\
\text { reduction and } \\
\text { growth } \\
\text { promotion. }\end{array}$ & $\begin{array}{l}\text { Partnership GBS (PGBS) was found } \\
\text { to improve harmonization, alignment } \\
\text { and policy development on all } \\
\text { countries reviewed, as well as having } \\
\text { a positive influence on allocative and } \\
\text { technical efficiency of public financial } \\
\text { management in five of the countries. } \\
\text { However, the study also found that } \\
\text { unpredictability and volatility of PGBS } \\
\text { were a problem. }\end{array}$ & $\begin{array}{l}\text { http://www.oecd } \\
\text { 746,en_215713e } \\
\text { 79_1_1_1_1,00. }\end{array}$ \\
\hline $\begin{array}{l}\text { Caputo, E., de } \\
\text { Kemp, A \& } \\
\text { Lawson, A. }\end{array}$ & $\begin{array}{l}\text { Assessing the } \\
\text { impacts of } \\
\text { budget } \\
\text { support: Case } \\
\text { studies in Mali, } \\
\text { Tunisia and } \\
\text { Zambia }\end{array}$ & 2011 & 2010 & Working paper & $\begin{array}{l}\text { General and } \\
\text { sector budget } \\
\text { support }\end{array}$ & $\begin{array}{l}\text { Mali, Tunisia } \\
\text { and Zambia }\end{array}$ & $\begin{array}{l}\text { Non- } \\
\text { experimental, } \\
\text { case study } \\
\text { approach }\end{array}$ & $\begin{array}{l}\text { Three country } \\
\text { case studies }\end{array}$ & $\begin{array}{l}\text { Extent to which } \\
\text { budget support } \\
\text { provides means } \\
\text { for } \\
\text { implementing } \\
\text { national and } \\
\text { sectoral } \\
\text { priorities } \\
\text { Efficiency and } \\
\text { effectiveness of } \\
\text { national } \\
\text { priorities } \\
\text { Sustainable } \\
\text { outcomes and } \\
\text { impacts on } \\
\text { growth }\end{array}$ & $\begin{array}{l}\text { They study found that budget support } \\
\text { had resulted in better budget } \\
\text { management, although its design, } \\
\text { harmonization and alignment ere not } \\
\text { optimal. In addition, the authors found } \\
\text { that budget support was associated } \\
\text { with increased public expenditure on } \\
\text { social services, which resulted in } \\
\text { improvements in health. For instance, } \\
\text { in Zambia increased health service } \\
\text { provision was associated with a } \\
\text { decrease in the incidence of } \\
\text { tuberculosis, malaria, diarrhoea and } \\
\text { maternal and child mortality. } \\
\text { However, the study highlights } \\
\text { concerns with respect to the quality of } \\
\text { these services. }\end{array}$ & $\begin{array}{l}\text { http://www.oecd. } \\
\text { 8934753.pdf }\end{array}$ \\
\hline $\begin{array}{l}\text { Visser-Valfrey, } \\
\text { M. \& Umarji, } \\
\text { M. B. }\end{array}$ & $\begin{array}{l}\text { Sector Budget } \\
\text { Support in } \\
\text { Practice } \\
\text { Case Study } \\
\text { Health Sector } \\
\text { in } \\
\text { Mozambique }\end{array}$ & 2010 & 2008 & Project report & $\begin{array}{l}\text { Sector budget } \\
\text { support }\end{array}$ & Mozambique & $\begin{array}{l}\text { Non- } \\
\text { experimental, } \\
\text { case study } \\
\text { approach }\end{array}$ & $\begin{array}{l}36 \text { stakeholder } \\
\text { interviews }\end{array}$ & $\begin{array}{l}\text { Extent to which } \\
\text { SBS has met } \\
\text { the objectives } \\
\text { of partner } \\
\text { country and } \\
\text { donors }\end{array}$ & $\begin{array}{l}\text { The study found an increase in the } \\
\text { number of donors engaging in sector } \\
\text { budget support, better co-ordination } \\
\text { and a positive influence on sector } \\
\text { management, policy and monitoring } \\
\text { and evaluation. However, it also } \\
\text { found that more progress is needed } \\
\text { in improving the budgeting process, } \\
\text { systems for financing de-centralized } \\
\text { services and technical assistance } \\
\text { and capacity development. }\end{array}$ & $\begin{array}{l}\text { http://www.odi.o } \\
6405 . p d f\end{array}$ \\
\hline
\end{tabular}




\subsection{Sector-wide approaches}

Sector-wide approaches (SWAPs) arose in the mid 1990s as a result of the prevailing discontent with project aid (Harrold and and associates 1995). Although there is no agreed definition of precisely what SWAPs involve, they are a co-ordination mechanism for donors working on the same sector that aims to improve donor co-ordination, government ownership and lower transaction costs of aid (Sundewall and SahlinAndersson 2006, Hutton and Tanner 2004). In essence, a SWAP represents a partnership between donors and the partner government, lead by the health ministry of the partner government (Hutton and Tanner 2004). The terms of this partnership are often agreed in advance, and vary between different countries (Sundewall and SahlinAndersson 2006). SWAPs are often associated with delivering aid as budget support, further supporting partner ownership and country systems.

\section{Box 1: Health sector-wide approaches in practice: the cases of Zambia and Bangladesh}

The sector wide approach was introduced in the Zambian health sector in 1993, with the aim of aligning and co-ordinating aid, as well as supporting the plans of the health ministry (ODI and Mokoro 2009). Chansa et al. (2008) carried out an evaluation of the Zambian SWAP in 2008 with the aim of assessing its contribution to efficiency, in the form of administrative, technical and allocative efficiency. The study found that the proportion of funds channelled through the SWAP made only modest increases during 1998-2005. In addition, the evaluation found that many donors were still operating outside the SWAP, with this trend increasing rather than moving towards a more harmonized approach. In terms of efficiency, the study found that the SWAP had resulted in small improvements in administrative efficiency, although transaction costs remained high, due to the amount and intensity of related meetings, which happened alongside meetings for donors operating outside of the SWAP $-\mathrm{a}$ fact probably enhanced by the arrival of global health initiatives in the time period of study. The authors of the evaluation found that both the funding to hospitals and the bed occupancy rate in these decreased since the introduction of the SWAP, resulting in a decrease in technical efficiency. Finally, the evaluation found small improvements in the allocative efficiency of the budget execution, particularly at the level of district funding. The results of this evaluation are disappointing, although the authors do not rule out the SWAP as a successful co-ordination model, they do conclude that the set up of the Zambian SWAP was not effective (Chansa et al. 2008).

The Bangladesh SWAP_known as the Health, Nutrition and Population Programme-started in 1998. It is often referred to as the biggest and oldest SWAP and has been the subject of a few evaluations. A study carried out by White (2007) found that the health SWAP in Bangladesh had succeeded in lowering transaction costs, and that the associated budget support had been a successful funding mechanism. However, the study also found that donors were still driving the policy process and that projects were too complex. Amongst the recommendations, White stressed the need for donors to adopt a more 'hands-off' approach, giving the government space to make their own decisions and restraining from criticism, whilst investing in its monitoring and accountability systems ((White 2007). Other studies of the Bangladeshi SWAP have found donors' unwillingness to fully participate due to lack of trust in country systems (Buse 1999) and that despite of the clear contributions the SWAP has made towards donor alignment and predictability, and strengthening national health policy, the SWAP has failed to bring about organizational and governance reforms, government ownership, as well as stopping donors from developing parallel systems (Martinez 2008). However, the failure of the SWAP mechanism to fully achieve its intended results is not seen as a consequence of the inappropriateness of the SWAP model, but rather as a result of its implementation. The lack of success is seen as a consequence of the poor quality of the underlying health plans and monitoring systems, rather than on the SWAP itself (Martinez 2008). 
Although the evidence on the impact of the sector wide approach mechanism on the health sector is mixed (Box 1), it is important to take into account that the SWAP mechanism involves a reform in the way aid is given and in the relationship between the donors and the government, which means it will take time for the impact to be seen (Hutton and Tanner 2004). In addition, the SWAP can be seen as a set of principles to give aid, but its implementation varies between the different countries, as the local political and cultural context have been found to influence the 'shape' of the SWAP in different countries, and hence its effectiveness (Sundewall and Sahlin-Andersson 2006).

\subsection{Budget support}

Budget support is a type of programme-based approach that is characterized by having little or no earmarking. There are two types of budget support: general budget and sector budget support. General budget support involves donors providing aid directly to the government's budget, linked to a poverty reduction strategy. Success of budget support is dependent on the governance and policy environment of the partner country, with concerns regarding corruption and misuse of funds (Bourguignon and Sundberg 2007). During 2002-06 only 6.4 per cent of all aid was allocated as budget support (Piva $P$ 2009), reflecting donors' concerns and unwillingness to engage in this aid modality. However, the popularity of budget support is growing (Marshall and Ofei-Aboagye 2004), particularly amongst European donors. A study of general budget support in seven countries over 1994-2004 found positive results in all but two countries. It found that, overall, it was a relevant aid modality and that general budget support increased government ownership, accountability and capacity for public financial management. In addition, it enhanced the quality of aid by improving donor harmonization and alignment (Dom 2007). These findings have been corroborated in further studies (Carter and Lister 2007; Marshall and Ofei-Aboagye 2004; Leader and Colenso 2005).

Although donors do not select how the funds are distributed, negotiations of general budget support can increase budget allocation to the health sector. In addition, budget support can be delivered as sector budget support, where funds are earmarked to a particular sector, often the health and education sectors. A study of ten sectors in six African countries found that sector budget support had improved the efficiency of public resource use by supporting planning, budgeting, management and accountability processes. However, it found that although access to services had been greatly expanded, the quality and equity in the delivery of these services had not (Williamson and Dom 2010). Another study found sector budget support to lower transaction costs of aid programmes (Dom 2007)

\subsection{Global health initiatives}

Recent increases in the levels of development assistance for health have not only been associated with different funding modalities but with the arising of new donors and initiatives. Since the year 2000, there has been a proliferation in global health initiatives (GHI), which tend to focus on a single disease or group of diseases. Some of the more prominent GHIs include the Bill and Melinda Gates Foundation, the Global Fund for AIDS, Tuberculosis and Malaria, the GAVI Alliance in support of childhood 


\section{Box 2: Global Health Initiatives}

Global Health Initiatives (GHIs) have been successful in bringing specific health problems into the global health agenda and in gathering large amounts of resources to tackle them. However, they have also been at the centre of criticisms for drawing resources away from broader health system issues and further complicating the aid architecture. Two large studies have been conducted to assess the interactions between GHIs and country health systems and the impact of GHIs on country co-ordination mechanisms.

The first of these studies, conducted by the Maximising Positive Synergies Collaborative Group at the World Health Organization, reviewed 221 existing reports and conducted 15 new studies to assess the interactions between GHIs and health systems. The study analysed these interactions in six different dimensions: health service delivery, health financing, governance, health workforce, health information systems and supply management systems.

The study found mixed results. In terms of health service delivery-defined as access, equity and coverage - the report found that while access to services targeted by GHIs increased, there was mixed evidence regarding access to other services. GHIs were accredited to have made some contribution to equity but not towards the causes of inequity or social determinants of health. In addition, whilst GHIs were found to improve quality by the provision of guidelines, there were also concerns that pressure on performance had compromised quality of services. With regards to health financing, it was found that GHIs resulted in an increase in funding, improved the availability of free services at the point of care (albeit not systematically) and contributed to improvements in predictability of aid funding. However, alignment with national priorities or the burden of disease was weak. GHIs were found to have an overall positive influence on health sector governance, by exposing weaknesses, improving accountability and productivity, and increasing capacity and community participation. Nevertheless, there were worries that the performance-based approach employed by GHIs may distort these indicators towards their specific targets. In terms of health information systems and supply management systems, GHIs have resulted in improvements in both, but only for their targeted diseases. In addition, they were also found to create parallel systems and, in the case of supply chains, to duplicate and displace local systems, resulting from a lack of co-ordination.

The study concludes that GHIs and country health systems are dynamic and inter-connected, and have positive and negative effects on each other, although policies to ensure the maximization of positive interactions are missing. The study recommends that the health systems strengthening agenda be given the same ambition and speed that characterises GHIs, to introduce health systems targets to existing GHIs, to improve alignment between GHIs and country health systems, for more data to be generated on costs and benefits of improving health systems, and for increases in funding for health systems in a predictable manner.

The second study, Spicer et al. (2010), examined the effects of three GHIs - the Global Fund to fight AIDS, Tuberculosis and Malaria (GFATM), the President's Emergency Plan for AIDS Relief (PEPFAR) and the World Bank's Multi-country AIDS Programme (MAP)—on co-ordination in seven countries in Europe, Asia, Africa and South America. The study involved 379 in-depth interviews with stakeholders at the national and sub-national level. Overall, it was found that different contexts actually shared similar experiences. The study found that GHIs, particularly the Global Fund, had a positive effect on national level co-ordination and have achieved wide stakeholder participation, although participation from nonhealth government departments and civil society organizations (CSOs) remained weak. Country ownership, on the other hand, was found to be inhibited by weak decision-making power of co-ordination mechanisms, particularly at the sub-sector level. Although some improvements in ownership were observed over time, the study found that a lack of transparency and communication, competition for resources, and weak secretariat and managerial capabilities were impeding further progress.

A number of recommendations to improve the co-ordination and therefore the effectiveness of GHIs are made. These include improving secretariat capacity at national and regional level through financial and technical support, better positioning of co-ordination mechanisms within government to enhance their authority, increasing financial and training support to CSOs to improve their participation at the national and regional level, and better definitions of the roles of the members of national and sub-national coordination structures. 
vaccination and the Stop TB Partnership. However, there are many others. Their increase in popularity (and funding) has sparked a debate between vertical, diseasefocused programme and horizontal health system approaches.

Proponents for 'vertical' disease-focused programmes advocate that the urgency of tackling the spread of some diseases means specific programmes have to be designed and implemented for them (Biesma et al. 2009, World Health Organization Maximizing Positive Synergies Collaborative Group et al. 2009). On the other hand, broader health systems constraints have been identified as slowing down progress towards making improvements in these diseases, and in health more generally (Cavalli et al. 2010, Lieberman et al. 2009, Shiffman 2006b). There has been mixed evidence on the impact of vertical programmes on the health system, although it has been found that weak health systems are particularly vulnerable to the negative effects of GHIs (Cavalli et al. 2010).

The evidence on which this debate is based is scarce, with both sides using anecdotal evidence to make their case. However, some recent studies have shed some light on this. A multi-country review carried out by the World Health Organization's Positive Synergies Collaborative Group (2009) found that although there were significant gaps in the data, there was potential for global health initiatives to positively interact and reinforce the health system. A seven-country study by Spicer et al. (2010) found that although GHIs (the Global Fund for AIDS, Tuberculosis and Malaria particularly) have had positive effects on co-ordination at the national level, they increased the complexity of the aid architecture, undermined alignment and lacked harmonization, especially at the sub-national level (Spicer et al. 2010). In contrast, Dodd and Lane (2010) found that global health partnerships have successfully innovated new approaches to raising and delivering funds and can provide longer-term funding, from which other donors should learn-more details on these can be found in Box 2.

A third 'middle' way has been put forward, known as the 'diagonal' approach. This approach consists of using single disease projects and programmes to address broader health systems issues, such as human resources, drug supply and financing (Frenk et al. 2003). However, there are warnings that unless accompanied by an increase in funding, this new approach will fail (Ooms et al. 2008). Examples of the diagonal approach include the Global Fund's health systems strengthening programmes 2 and PEPFAR's investments in human resources, supply chains and health systems infrastructure (Moore and Morrison 2007).

\section{$4 \quad$ Factors affecting the effectiveness of DAH}

\subsection{Allocation of DAH}

As outlined in the introduction, the amount of DAH disbursed has increased dramatically over the past ten years. However, this increase has been uneven both between countries and across different health priorities. The share of DAH allocated to sub-Saharan Africa (SSA) has increased steadily (albeit departing from low levels of investments in the sector, see Table 1) to account for 29 per cent of all DAH in 2008,

2 Globa Fund to fight AIDS, Tuberculosis and Malaria (2007). 
making it the best-funded region in the world (Institute for Health Metrics and Evaluation 2010), which also reflects the severe deficits in health service provision in the region.

A cross-country analysis found no correlation between countries' GDP per capita and the amount of DAH they received, although this is improving (Ravishankar et al. 2009). This should not be taken as a measure of whether DAH has resulted in increased growth, but rather as an assessment of whether DAH is provided to countries that need it most. Some problems arise when contrasting total DAH with GDP per capita, as a few newly emerging middle-income countries—such as India, Pakistan and China-have large populations and receive large total amounts of foreign aid. India was actually the largest recipient of DAH in 2007; however the per capita DAH it received is actually low compared to almost all lower-income countries. Given that expressed motive for development assistance is to aid poor countries, DAH distribution is fairly consistent with this motive. Figure 1 shows the relation between the cumulative proportion of poor (defined as living under US\$1 a day) and the cumulative amount of health official development assistance (ODA) distributed for 56 countries, including India and China, but excluding countries with a population smaller than one million and for which DAH made up less than 1 per cent of their total government budget. These countries were ranked by per capita income, averaged over 1995-2006. For this sample of countries, the first 25 countries amounted to containing 26 per cent of the total poor while the amount of health ODA going to these countries amounted to 51.5 per cent of the total amount of aid in our sample. Of these countries 22 were in SSA, two in South Asia and one in Central Asia. The $26^{\text {th }}$ country is India, home to 44 percent of the poor people in our sample. India received 17 per cent of the health ODA. At the point of India in Figure 1 the cumulative proportions are equalized.

Figure 1: Cumulative distribution of health ODA in relation with the distribution of poor in 2006

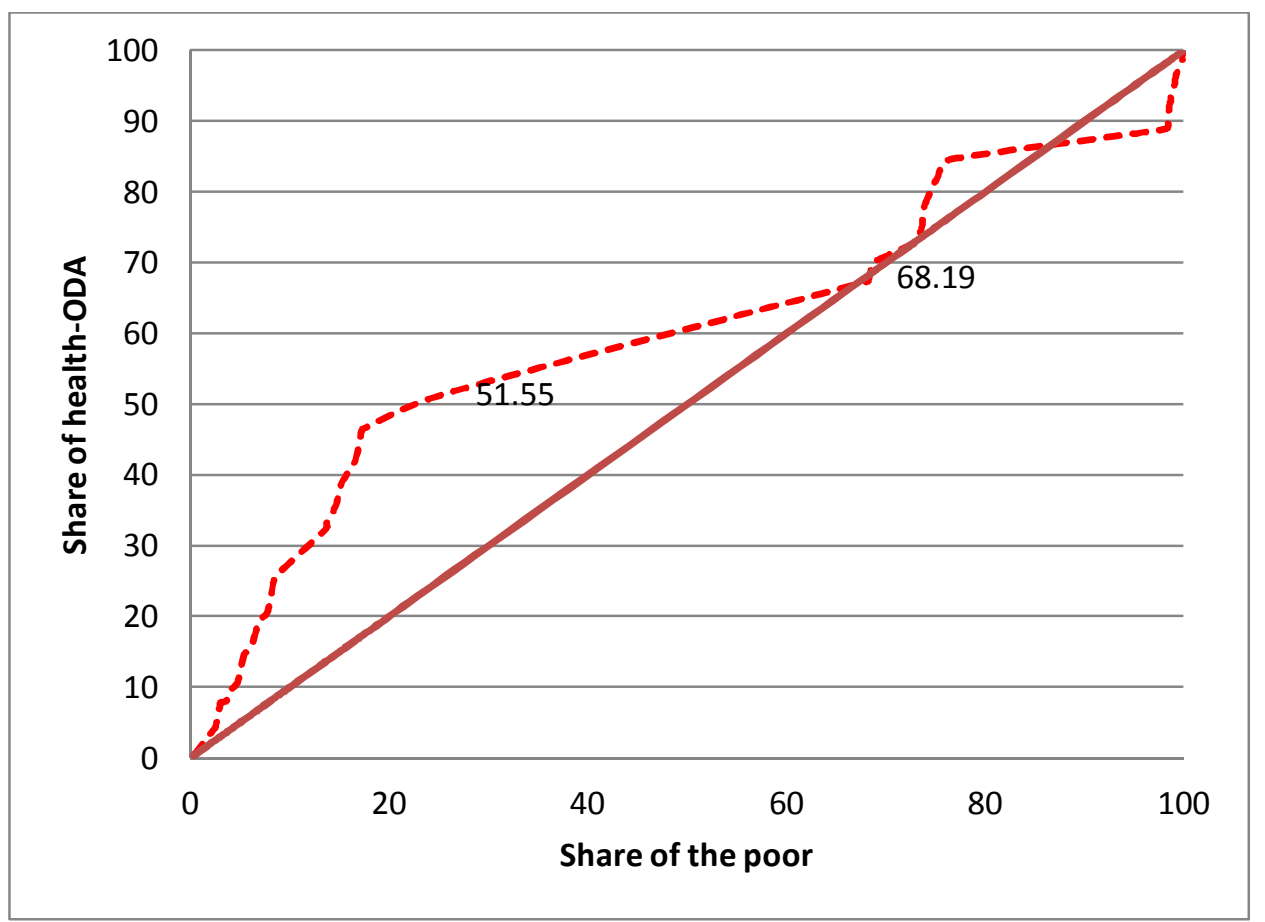

Source: authors' illustration using OECD and World Bank poverty data from 2004-06. 
Another indicator that may be important is the proportion of total health expenditure that DAH makes up; after all, DAH should make up the short-fall in health expenditure for poor countries. The evidence suggests that DAH measured as the amount going into a country makes up a larger share of total health expenditure for poor countries. Figure 2 depicts this relationship. Here we show that DAH is distributed in a pro-poor manner. In some countries DAH does nearly make up the entire public sector health budget. Although the political economic implications of this relationship are not clear, $\mathrm{DAH}$ makes up a large proportion of the health expenditure and budget for poor countries.

Figure 2: DAH as a share of total health expenditure and log income, average 2004-08

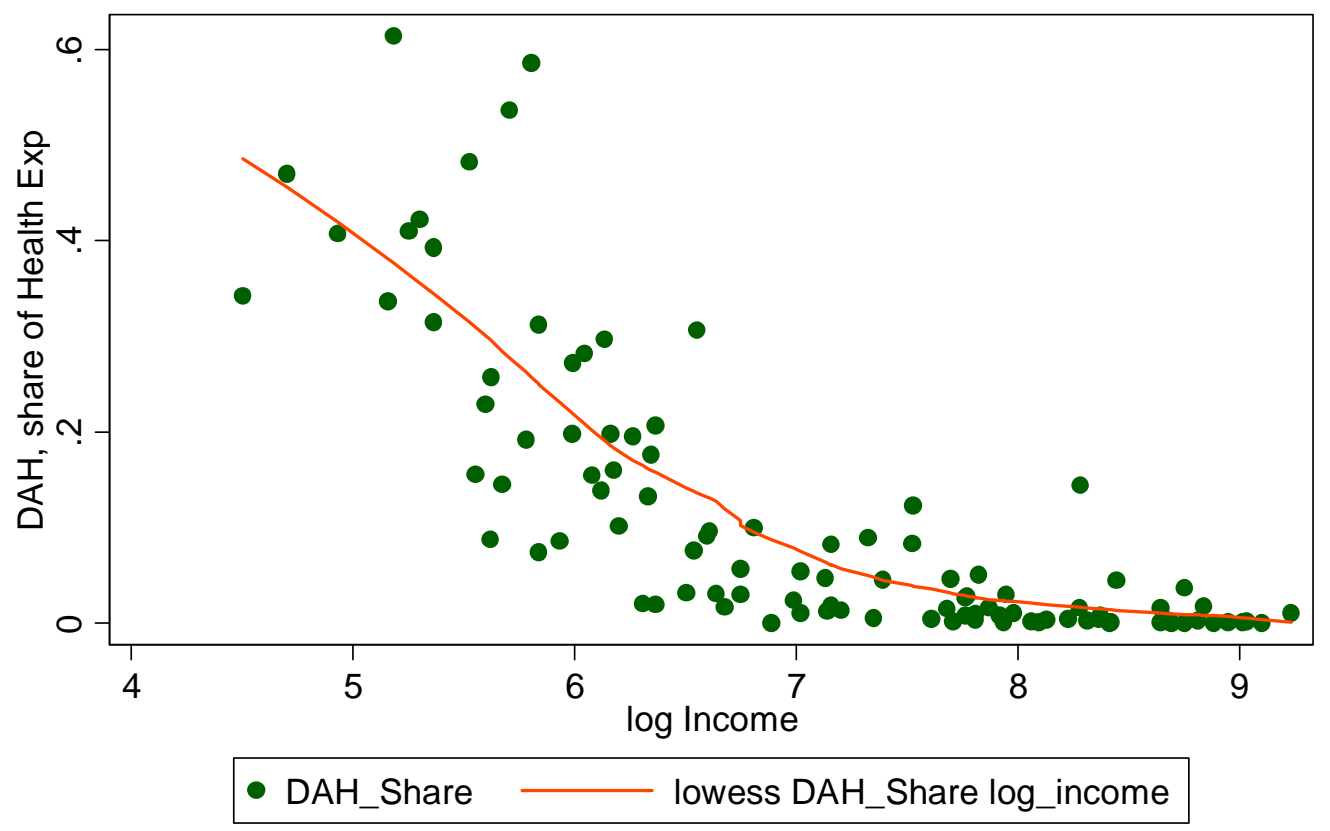

Source: authors' illustration using OECD and World Bank income data 2004-08.

Given the increase in earmarked project funding, one implication of the foreign source of health expenditure being large centres on whether the project funding meet the priorities within a country. The literature highlights some (but not full) correlations between countries' burden of disease and the level of funding they receive (Ravishankar et al. 2009; MacKellar 2005). For instance, Ravishankar et al. (ibid.) found that of the US\$13.8 billion DAH in 2007 for which project-level information was available, US $\$ 4.9$ billion was spent on HIV/AIDS, compared with US\$0.6 billion on tuberculosis, US $\$ 0.7$ billion on malaria, and US $\$ 0.9$ billion on health sector support. Another study found that non-communicable diseases received US\$0.78 per disability-adjusted life year (DALY) in 2007, compared to US\$23.9 per DALY attributable to HIV, tuberculosis, and malaria (Nugent 2010). Differences in funding are also observed amongst the goods and services that are funded; for instance, more funding is allocated to the procurement of drugs than to human resources or infrastructure (Juliet et al. 2009). Analysis of OECD Creditor Reporting System data shows the prominence of HIV funding, but also recent increases in broader health systems priorities: 
Figure 3: Trends in priorities of development assistance for health (2009 constant US\$ billion commitments)

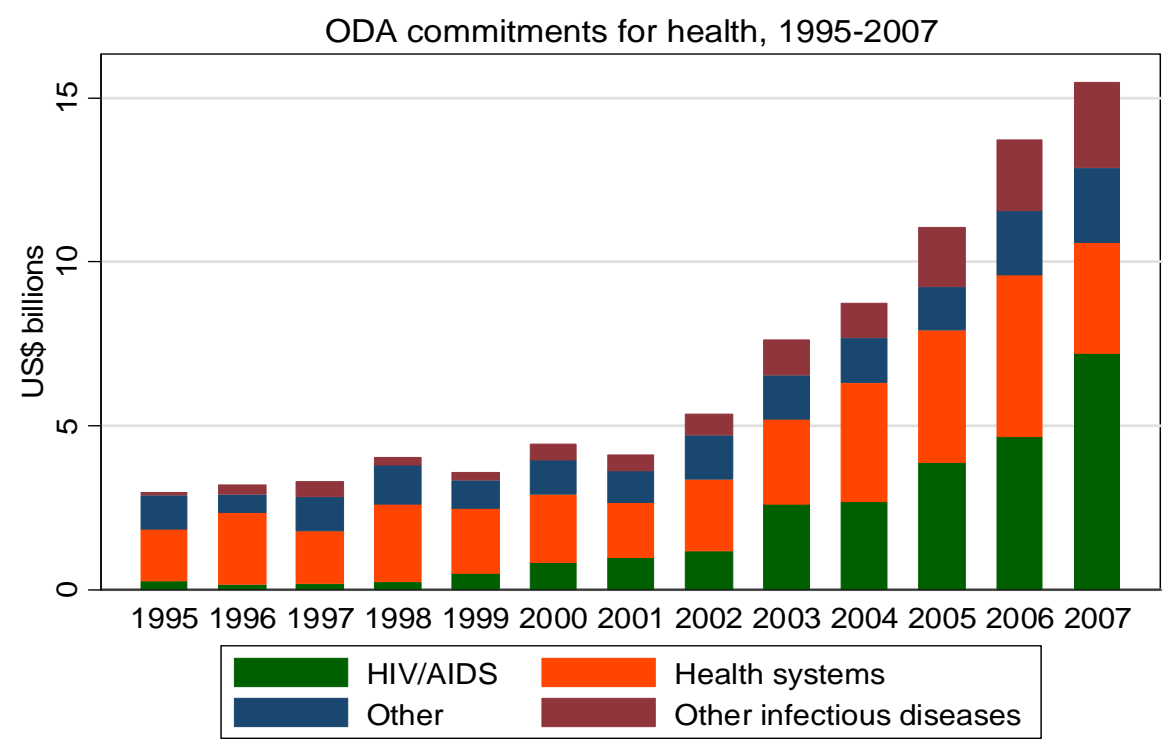

Source: Tandon (unpublished), compiled from OECD-DAC data, reproduced with permission from author.

If funding decisions are not fully based on disease burden, then what other factors are influencing donors' choices? Discussions in the literature indicate that donors have nonaltruistic motives. Countries may use DAH as a strategy within their foreign policy and security (Labonte and Gagnon 2010); for instance, to control infectious diseases that pose a threat to donors' national security (Shiffman 2006a; Shiffman et al. 2002). In addition, there is some evidence that priorities are set to serve the interest of donor countries’ foreign policy and trade agenda (Feldbaum and Michaud 2010).

The current distribution of DAH affects its effectiveness in two ways. First, resources are not directed to where they are most needed, and hence are not achieving their potential impact. Second, the popularity of some countries and priorities means that donors and implementing agencies crowd around them, resulting in duplication and competition (see fragmentation below).

\subsection{Predictability}

By its very nature, DAH is discretionary spending for donors, and as such can be extremely unpredictable. Predictability is defined by the OECD as the provision of long-term indicative figures of aid flows, as well as the disbursement of committed funds in a timely manner (OECD 2008a). Donors often fail in both dimensions. A panel regression in 60 low-income countries for the time period 1990-2005 found that, on average, levels of annual aid disbursements and commitments differed greatly, particularly in SSA. It also found that this had only shown small improvements over time. Perhaps surprisingly, lack of predictability was found both as shortfalls and as excesses in the amounts of funds expected, with SSA countries more likely to receive excess disbursements (Celasun and Walliser 2008). This has been corroborated in single-country studies in Uganda (Orem et al. 2009) and Zambia (Sundewall et al. 2009). Other studies have found significant differences between countries (Strategic Partnership for Africa-Budget Support Working Group 2005), and that the poorest 
countries are particularly affected by the unpredictability of DAH (Celasun and Walliser 2008).

Different reasons are found in the literature for the lack of predictability of aid flows. A survey of donors found that unmet policy conditions, donor administrative problems, recipient government delays in meeting conditions and political problems in the donor country all contributed to a lack of predictability (Strategic Partnership for AfricaBudget Support Working Group 2005). Celasum and Walliser (2008) found that 25 per cent of unpredictability was explained by recipient country stability and levels of aid disbursed. They blamed the rest on 'fickle' donor behaviour (Celasun and Walliser 2008). This lack of predictability has lead to DAH only funding the developing budget in countries such as Tanzania, as recurrent costs need to be constant, and hence it is risky to have them depend on external assistance.

Lack of predictability can hinder aid effectiveness in several ways. First, it hinders recipient governments' ability to plan their budgets (Orem et al. 2009). This is a particularly important problem in the health sector, as health systems development is a long-term process, where many costs are recurrent, resulting in governments being reluctant to scale up activities (Vassall and Martinez Alvarez 2011, Dodd and Lane 2010). Furthermore, budget aid that is larger than planned for may not be incorporated into the budget, and its expenditure will either be delayed or allocated to recurrent rather than investment spending. Second, lack of predictability has resulted in recipient ministries of finance being unwilling to allow long-term health spending commitments (Cavagnero et al. 2008), hence contributing to fungibility. Third, unpredictable aid undermines recipient governments' budgets by forcing adjustments in expenditure and changes in original allocations during budget execution, hindering the achievement of government objectives, and disrupting the implementation of poverty reduction strategies (Celasun and Walliser 2006).

\subsection{Fragmentation}

As mentioned in Section 2, increased levels of development funding have resulted in the proliferation of the number of donors and the amount of projects and programmes they fund. This phenomenon is known as fragmentation. Fragmentation, which has been associated with decreased DAH effectiveness, affects countries differently (Frot and Santiso 2010). A study by Frot and Santiso (2010) found that poor and stable democratic countries, such as Tanzania, which had 1,601 aid projects in 2007, suffer most from fragmentation. The authors suggested that this was associated with donors preferring stronger institutions, which are found in these countries.

There are several reasons why fragmentation of DAH decreases its effectiveness. Acharya et al. (2006) classify these as direct and indirect costs. The direct (transaction) costs are a result of both the large number of donors, which require substantial amounts of senior officials' time, and the amount of projects they fund, which incur a considerable managing and reporting burden for governmental authorities (Acharya et al. 2006). Indirect costs include aid agencies attracting public servants away from the government, thereby exacerbating staff shortages (Aldasoro et al. 2010); time and money spent by donors on technical assistance and training of local staff, which results in reduced worker productivity (Acharya et al. 2006; Mueller et al. 2011); governments finding it easier to protect their interests as donors can exert less pressure by acting 
alone (Burnell 2002), but having to balance out many different interests; more difficult co-ordination resulting in duplication; and, lack of individual sense of responsibility (Knack and Rahman 2007).

\subsection{Fungibility}

The issue of fungibility is often hotly debated in discussions concerning the effectiveness of DAH. Methodological issues encountered when assessing fungibility were discussed in Section 2. Here, we outline the current views on the matter. Fungibility is the process by which the recipient government 'offsets donor spending for a particular purpose by reducing its own expenditures on the same purpose ... therefore aid substitutes rather than supplements local spending' (Foster and Leavy 2001). The existence of fungibility of development assistance has been documented extensively in the literature from as early as 1993 (Pack and Pack 1993, World Bank 1998). Fungibility can occur at the macroeconomic (Gottret and Schieber 2006), sector (Farag et al. 2009, Gottret and Schieber 2006, Lu et al. 2010) and subsector (Shiffman 2008, Gottret and Schieber 2006) level. Although the data available on health sector spending in low-income countries is often scarce and of bad quality, several studies have found that it is particularly affected by fungibility (Lancaster 1999). Estimates of the extent of fungibility in the health sector for every dollar spent vary from a decrease in US\$0.27$\$ 1.65$ (Farag et al. 2009, Gottret and Schieber 2006, Lu et al. 2010) to a US\$1.50 increase (Mishra and Newhouse 2007). Much of these calculations in regards to DAH depend on methodologies used including how the dependent variable is constructed. Some attempt needs to be made in regards to critically survey this literature.

Merely documenting whether fungibility takes place is insufficient, it is more important to explore why it happens (Lahiri and Raimondos-Moller 2004; Ooms et al. 2010) and whether it is detrimental to DAH effectiveness. Some factors have been associated with increased fungibility, including low levels of recipient country income (Farag et al. 2009), fragmentation (Gottret and Schieber 2006), lack of predictability and the shortnature of DAH flows (Farag et al. 2009; Gottret and Schieber 2006), and lack of information (Halonen 2004). It is also important to explore why governments may choose to divert their spending from the health sector. It may be a government's way of reallocating funding to other sectors, to anticipate the long-term unreliability of DAH, or to smooth DAH by spreading it across different years (Farag et al. 2009), a practice advised by the IMF (Stuckler et al. 2011).

Fungibility is often highlighted as a cause of aid ineffectiveness, as donor funds substitute rather than complement recipient governments' budget for health, and some studies consider it synonymous with corruption (Lahiri and Raimondos-Moller 2004). However, fungibility has also been described as a rational and responsible response to DAH, resulting from donors' and recipients' differing priorities (Gottret and Schieber 2006; McGillivray and Morrissey 2000), where recipient governments reallocate the resources available to them according to their priorities (Waddington 2004). It may be seen as an indication that the recipient governments are aware of the DAH coming into the country, which may explain why funds channelled through NGOs do not result in fungibility (Sridhar and Woods 2010). In addition, some studies have concluded that fungibility has limited consequences (McGillivray and Morrissey 2000; Wagstaff 2011), that it is too narrow a concept to analyse aid effectiveness (Pettersson 2007), and that it may distract from the real issues (McGillivray and Morrissey 2000). 


\subsection{DAH relationships}

In Section 2 we mentioned that the process of giving aid is in itself often a subject of study. Here we outline the current thinking on these issues. It is first important to acknowledge that DAH ineffectiveness is not just the responsibility of a particular actor or agency, but of the system of relationships that it generates. A variety of actors are involved in the delivery and use of DAH. These actors form dynamic and interactive relationships, which are shaped by differing underlying incentives, motivations, and information and power asymmetries and often result in lack of accountability (Eyben 2006, Holvoet and Renard 2007, Gibson et al. 2005, Alonso 2004). This section will explore the notions of accountability, incentives and information and power asymmetries that characterise DAH relationships.

Accountability is understood as the 'means by which individuals and organizations are held responsible for their actions' (Edwards and Hulme 1996). It is considered vital to the effectiveness of $\mathrm{DAH}$, and has been repeatedly called for in the various declarations and commitments to aid effectiveness (Organisation for Economic and Development 2008, Balabanova et al. 2010). Accountability should happen at all stages of the aid process, from decision-making, through implementation, monitoring, and evaluation (Kapur and Whittle 2010). There are four components to a well-functioning accountability system: a clear statement of goals (ODA 1993), transparency of decisionmaking and use of funds (Ebrahim 2005; Ebrahim 2010, World Bank 2006), an appraisal process with published results (Ebrahim 2010; ODA 1993), and mechanisms for holding those responsible to account (ODA 1993).

In theory, beneficiaries should hold donors and implementing agencies to account, and donors and implementing agencies should be mutually accountable to one other for the distribution and outcomes of DAH. However, accountability should not be regarded as a linear process, as the many actors involved interact to form a complex web of relationships (Ebrahim 2005; Eyben 2006).

Repeated calls for mutual accountability between donors and recipient governments have proven difficult to implement in practice. Several reasons have been put forward in the literature for this. First, the DAH system faces the problem of being a 'global public good', where every country can benefit from improved health indicators and development in general (Alonso 2004), which may result in donors eluding individual responsibilities, as the rewards will be shared amongst all donors. Second, donors' main accountability line is to their funders - the taxpayers (Haan 2009), and they therefore feel less responsibility towards the recipient government for their actions. Donor incentives are also often skewed towards spending of funds rather than achieving results, a trend known as the 'money-moving syndrome' (Monkam 2008b), which hinders accountability to beneficiaries. Third, accountability lines within donors mean that country offices are accountable to their headquarters, rather than the recipient government. Given the different motivations for giving DAH, country offices may be forced to follow the 'official line', even if that means bypassing mechanisms of country ownership, harmonization and alignment. Long project cycles and short-term posts in donor offices have also been blamed for hindering accountability (Monkam 2008a).

Lack of trust in recipients' accountability mechanisms has resulted in donors either setting up parallel systems, which further undermine the government (Buse 1999), 
attaching conditions on how assistance is managed and accounted for, which limits its predictability and country ownership, or attempting to improve governments' systems through technical assistance, which has been blamed for wasting resources on international consultants or luring government employees away from their jobs for training purposes with per diems or salary top-ups (Mueller et al. 2011).

Recipient governments and those implementing DAH funded services may not be fully accountable to their beneficiaries due to a phenomenon known as the 'broken feedback loop', whereby the people paying for the services are different to those receiving them (Easterly 2008). This is slowly changing, however, largely due to the advocacy efforts of increasingly stronger CSOs, both in donor and recipient countries.

Accountability is also hindered by power inequality between donors and recipients (Eyben 2006), as donors have control over resources, and can withdraw them at any point if they feel the recipient governments are not adhering to the conditions attached to the DAH (Ebrahim 2003). In contrast, there is no mechanism for sanctioning donors if they default on their commitments (Eyben 2006). Having said this, donors also face the Samaritan's dilemma, which arises when the cost of enforcing conditionality (i.e. withdrawing DAH) is higher than the cost of the conditions not being met (Gibson et al. 2005).

\section{Scalability of aid-supported health care programmes}

The aid influx into some countries, particularly to African and some of smaller South East Asian countries has increased the overall public expenditure on health dramatically. Consequently, scaling up of public activities around health has been observed for many of these countries.

However, several barriers, both financial and non financial, have been encountered when trying to scale up aid-funded health programmes (Hanson et al. 2003). A review by Mangham and Hanson (2010) highlighted absorption capacity and health system needs as key constraints to scaling up health interventions. Concerns regarding absorption capacity arise due to micro- and macro-economic constraints countries face in using additional aid resources effectively. There are worries regarding the effect increased development assistance may have on the partner governments' ability to plan, manage, and budget these resources, and their impact on service delivery (De Renzio 2005, 2007; International Monetary Fund 2007). There are also concerns about diminishing returns of increased aid, although studies have shown that these levels of funding have not yet been reached (Bourguignon and Sundberg 2006; Feeny and McGillivray 2011). Non-financial barriers to scaling up aid-funded health programmes can be encompassed as health system needs. These include the capacity of health workers and the appropriate policy and institutional framework that need to be in place for additional assistance to be used effectively (Mangham and Hanson 2010).

Two further concerns are quality and equity (Mangham and Hanson 2010). There are worries that scaling up health services will decrease the quality of those services, particularly if health systems needs for the scale up are not in place. For this to be prevented, it is important that additional expenditure on health infrastructure is accompanied by increased recurrent spending to support the additional health sector 
supply. There is some evidence that this is happening, with the Global Fund funding the construction of facilities, training health care personnel as well as improving the availability of medicines (Yu et al. 2008; Schwartlander et al. 2006). Moreover, there may exist a trade off between efficiency and equity when scaling up health programmes. This is because it would take more resources to reach the poorest populations, as they are often hardest to reach, and therefore scale ups that aim to reach as many people as possible may not reach in these populations (Mangham and Hanson 2010). This has been found to be the case in two studies evaluating the affordable medicines facility for malaria initiative and the evaluation of the ' 3 by 5 Initiative' by the WHO. 3 In both cases they found that although the interventions had achieved wider coverage, this tended to be focused on the upper quintiles, with the poorer populations still experiencing the most acute shortages of medicines (Battistella Nemes et al. 2006; Cohen et al. 2010).

Work undertaken by Hanson et al. (2003) identified five levels at which the above constraints can operate, and to which interventions to address them should be aimed. The first is at the level of the community and household, where the key constraints are lack of demand and use of interventions. The second is at the level of health services delivery, which includes health systems issues, such as the quantity and quality of human resources, availability of drugs and medical supplies, etc. The third level of constraints is at the level of health sector policy and strategic management, where constraints include lack of adequate policies and incentives and over-reliance on donor funding. The final level includes public policies cutting across sectors and environmental and contextual characteristics, such as governance and the overall policy framework.

Despite all of the above, many examples can be found in the literature of successful scale up interventions (see Table 4 for a summary of these). A study of the scale up of an adolescent and sexual health programme in Tanzania was reported to achieve high coverage. The authors associate the success of the scale up with the structured nature of the process. However, they express concerns regarding the quality of the programmes and the need for increased supervision (Renju et al. 2011). In a set of case studies carried out by Medlin et al. (2006), the authors found that country ownership, strong leadership and management, and realistic financing were all associated with effective scale up of programmes. Similarly, three case studies conducted as part of the commission of macroeconomics and health in Chad, India, and Tanzania highlight the importance of addressing demand and supply issues by engaging with the community to integrate their needs and perceptions, and managing human resources and health infrastructure (Wyss K et al. 2003). They also highlight the need for clear objectives and information systems for monitoring progress, strong evidence-based technical design and innovative approaches to address constraints at the policy and management level (Rao Seshadri 2003), and the importance of sequencing and addressing policy and infrastructure constraints, often outside the health ministry (Munishi 2003).

3 WHO (2009); http://www.who.int/3by5/en/. 
Table 4: Summary of successful scale-up intervientions

Title and authors

Steketee, R. W. and T. P. Eisele (2009). 'Is the scale up of malaria intervention coverage also achieving equity?' PLoS One 4(12): e8409.

\section{Study summary}

Review of Demographic and Health Surveys, Multiple Indicator Cluster Surveys, and Malaria Indicator Surveys in African malariaendemic countries in the time period of 2006-2008. The study found great variation between levels of coverage of insecticide-treated mosquito nets (ITNs), treatment rates and intermittent preventive treatment (IPTp). Furthermore, the authors found that 52 per cent of the countries studied had an equitable distribution of ITNs, 30 per cent of treatment coverage and IPTp in pregnant women was higher in urban and richer households. This study shows that equitable scale up of malaria programmes is possible, although only two countries achieved equity in all three areas, with distribution of mosquito nets achieving higher coverage levels. The study found that countries with higher coverage did not necessarily achieve higher levels of equity. Furthermore, they conclude that two factors are associated with higher equity: the policies and delivery strategy, and the quality of delivery systems available.

Wolkon, A., J. L. Vanden Eng, et al. (2010). 'Rapid scale-up of long-lasting insecticide-treated bed nets through integration into the national immunization program during child health week in Togo 2004'. Am J Trop Med Hyg 83(5): 1014-1019

Cohen, J. M., O. Sabot, et al (2010). 'A pharmacy too far? Equity and spatial distribution of outcomes in the delivery of subsidized artemisinin-based combination therapies through private drug shops'. BMC Health Serv Res 10 Suppl 1: S6.

Scott, V. E., M. Chopra, et al. (2005). 'How equitable is the scaling up of HIV service provision in South Africa?' S Afr Med J 95(2): 109-113.

Renju, J. R., A. B. A. Bahati, et al. (2011). 'Scaling up adolescent sexual and reproductive health interventions through existing government systems? A detailed process evaluation of a schoolbased intervention in Mwanza Region in the Northwest of Tanzania'. Journal of Adolescent Health 48(1): 79-86

\begin{tabular}{|c|c|}
\hline $\begin{array}{l}\text { Improving the Health } \\
\text { Populations: } \\
\text { Experience (Medlin, C. A., } \\
\text { Ex } \\
\text { Chowdhury, et al. 2006). }\end{array}$ & $\begin{array}{l}\text { This series of } 17 \text { case studies found that country ownership, strong } \\
\text { leadership and management, and realistic financing were all } \\
\text { associated with effective scale up of programmes. }\end{array}$ \\
\hline $\begin{array}{l}\text { Wyss } \mathrm{K} \text {, Moto } \mathrm{DD} \text {, et al } \\
\text { "Constraints to scaling }\end{array}$ & $\begin{array}{l}\text { This paper reports on an assessment of the barriers to scaling } \\
\text { ealth interventions in Chad. It highlights the importance }\end{array}$ \\
\hline
\end{tabular}
is study analyses the coverage of a campaign to scale up ownership of ITNs by integrating ITN delivery with the vaccination campaign in six regions of Togo. The authors conducted communitybased cross-sectional surveys one and nine months after the campaign to assess coverage, equity and use of ITNs. The study found that the intervention achieved high levels of coverage and equity, even nine months post-campaign. Despite high levels of coverage, however, the study found low levels of use of ITNs. The authors of this study conclude that integrated campaigns are an effective way to scale up coverage, and therefore recommend this strategy to other countries. In addition, they reinforce the message that distributing ITNs free of cost was key in achieving high coverage. This study assesses the effectiveness of a pilot subsidy for artemisinin-based combination therapies (ACTs) used for malaria treatment in two districts of Tanzania. The study consisted of a baseline and four follow up surveys in the form of exit interviews over a period of 15 months. The results from the study indicate that although sales of ACTs increased substantially, there were significant geographical variations with shops closer to towns, main roads and accessed by individuals of higher socioeconomic status experiencing higher stocking and sales of ACTs. The study concludes that additional efforts are needed to achieve equity as this subsidy is scaled up across different countries.

This study reports on the findings of a cross-sectional descriptive study on the availability and use of HIV programmes, as well as management and support structures, in three districts of South Africa. The findings from the study reveal inequalities in service delivery between the richer, urban site and the poorer rural ones. The study concludes that the scale up of HIV services is exacerbating inequalities in service delivery and calls for policy makers to take into consideration equity issues as these may lower the effectiveness of interventions.

This study reports on the scale up of a school-based reproductive and sexual health programme in Tanzania. The study found that the 10fold scale up achieved a high coverage, which the authors attribute to the structured nature of the process. However, the authors express worries that this may have come at the cost of quality of the intervention. The study recommends higher levels of supervision and incentives to improve on this. 
related interventions: the case of Chad, Central Africa'. Journal of International Development 15(1): 87-100. scaling up health programmes: a comparative study of two Indian states'. Journal of International Development 15(1): 101-114.

Schneider, H., D. Coetzee, et al. (2010). 'Differences in antiretroviral scale up in three South African provinces: the role of implementation management'. BMC Health Serv Res 10 Suppl 1: S4.
Rao, S. S. (2003). 'Constraints to

addressing demand and supply issues by engaging with the community to integrate their needs and perceptions, and managing human resources and health infrastructure.

This study analyses the constraints phased by two Indian states when scaling up health interventions. It finds that in order to be successfully scaled up, programmes need clear objectives and information systems for monitoring progress, strong evidence-based technical design and innovative approaches to address constraints at the policy and management level.

This study compares the operational and strategic management of the antiretroviral therapy (ART) scale up in three provincial governments in South Africa, which had achieved different levels of coverage. The findings of the study reveal that although similar approaches were adopted for chronic disease care amongst the three provinces, differences were observed on political and managerial leadership, programme design, monitoring and evaluation systems and the nature and extent of external support and partnerships. The paper concludes by highlighting the importance of the managerial process for successful scale up of programmes.

Abuya, T., A. Amin, et al. (2010). This paper compares the scale up processes of private medicine 'Importance of strategic retailers in three districts in Kenya. It found that technical support and management in the sufficient resources were essential for successful scale up, although implementation of private not enough. The paper found that an effective strategy for managing medicine retailer programmes: relationships and strong and transparent management systems are case studies from three districts also needed.

in Kenya'. BMC Health Serv Res 10 Suppl 1: S7

Seymour, J. (2004) Controlling tuberculosis in China. Millions Saved: Proven Successes in Global Health. What Works Working Group. M. Kinder. Washington, DC, Centre for Global Development.

Source: authors' illustration.

\section{Discussion}

This paper has provided a brief history of aid, and of the literature on aid effectiveness. In doing so it has highlighted the inherent methodological difficulties found when trying to ascertain the impact of aid on development and growth broadly and the health sector specifically. The key impediments to effective development assistance for health are summarized, including allocation of resources, donor fragmentation, fungibility of funding and issues associated with the process of giving aid such as accountability, power and information asymmetries. The different aid modalities, their success stories and failures are also summarized. In particular, the shift from project aid to programmebased approaches is discussed, and the implications and constraints of scaling up successful projects reviewed.

One thing that has become clear when looking at success stories in economic development over the last 50 years, is that the development process required thorough diagnosis of local contexts, which was followed up by eclectic policy prescriptions, where conflicting theories were at work even within one single country (Rodrik 2010). Whilst the overall 'best practice' principles endorsed at international fora on aid effectiveness are noble and have generally been found to improve the quality of development assistance (Working Party on Aid Effectiveness 2009), they are very 
general, often unrealistic and need to be adapted to the local context. In addition, the international community has not managed to abide by them, although efforts seem to be moving in the right direction. Therefore transferability of 'best practice' is hard, particularly given that successful projects and programmes tend to be those that adapt best to the local circumstances and where there is real ownership by the local partners.

It cannot, however, be denied that low-income countries do share some common characteristics, and that opportunities for cross-country learning abound. This does not necessarily have to take place by directly trying to replicate success stories, but by taking into account what worked under what circumstances. In that sense, new and emerging donors engaging in South to South co-operation can provide significantly valuable expertise, some of them being aid recipients until recently themselves (or still receiving aid). With that in mind, a new form of co-operation, known as triangular cooperation, has emerged, where traditional donors-belonging to the Development Assistance Committee (DAC) of the OECD—provide assistance to support southern donors' programmes, given their technical advantage. An example of this is Germany's support for Brazilian HIV programmes across Latin America (Working Party on Aid Effectiveness 2009). Table 5 shows some further examples of triangular co-operation.

Table 5: Examples of triangular co-operation in the health sector

\begin{tabular}{|c|c|c|c|}
\hline DAC donor & Emerging donor & Recipient country & $\begin{array}{l}\text { Project/Programme } \\
\text { description }\end{array}$ \\
\hline Canada & Brazil & Haiti & $\begin{array}{l}\text { Haitian National Vaccination } \\
\text { Programme strengthening }\end{array}$ \\
\hline Japan & Brazil & Angola & $\begin{array}{l}\text { Development of human } \\
\text { resources for health in Josina } \\
\text { Machel Hospital }\end{array}$ \\
\hline Japan & Brazil & Madagascar & $\begin{array}{l}\text { Child health services } \\
\text { improvement programme }\end{array}$ \\
\hline UK & Brazil & Peru & HIV control \\
\hline US & Brazil & $\begin{array}{l}\text { São Tomé and } \\
\text { Príncipe }\end{array}$ & $\begin{array}{l}\text { Malaria control and } \\
\text { prevention }\end{array}$ \\
\hline Italy & Tunisia & Niger & Training of health workers \\
\hline Japan & Mexico & Nicaragua & $\begin{array}{l}\text { Integrated management of } \\
\text { plagues }\end{array}$ \\
\hline Japan & Sri Lanka & $\begin{array}{l}\text { Various African } \\
\text { countries }\end{array}$ & Hospital management \\
\hline
\end{tabular}

Source: adapted from http://www.oecd.org/dataoecd/62/54/44652734.pdf.

Few studies evaluating aid practices by new and emerging donors can be found in the literature. However, so far the evidence indicates that there are no significant differences between new and old donors in their distribution and practices, except that new donors do not appear to be influenced by the level of corruption of the recipient country when making decisions about aid allocation (Dreher et al. 2011). Emerging donors have been praised for bringing extra funds, but there are concerns about increasing fragmentation, their high levels of tied aid, a lack of engagement in dialogue with partner countries and an unwillingness to harmonize with other donors (Working 
Party on Aid Effectiveness 2009). Other characteristics of non-DAC donors are that they provide more flexible assistance, and mainly engage in project assistance and technical co-operation (Working Party on Aid Effectiveness 2009).

The international community has begun to acknowledge the importance of new donors, and of south to south co-operation, and has made efforts to include them into the highlevel fora on aid effectiveness. However, new donors did not adopt the Busan Partnership, but agreed to use its commitments and principles as reference for SouthSouth co-operation on a 'voluntary basis' instead. Although many see their engagement in the forum as progress, there is clearly some way to go before they are fully integrated.

As a last word, worries that the increasing levels of DAH seen over the past ten years will not be sustainable have contributed to increased attention to the effectiveness of aid. They have also resulted in donors taking a closer look at how they spend their finances and more pressure to be accountable to their funders (taxpayer, other donors) to show 'results'. This has lead to an increased emphasis on results and performance-based financing. There is also anecdotal evidence that some prominent donors are moving away from programme-based approaches, due to frustrations about the lack of progress and the increasing need to show results, which are harder to see in modalities such as budget support. Given the lack of clear evidence, and the difficulties in establishing whether DAH is effective, there is a danger that the international community keeps moving to different approaches due to external pressures without stopping to evaluate what has worked or failed and why. In addition, the results based agenda is problematic given the short window of analysis used. As discussed in Section 2, health as development is a long-term process, the results of which may take years to fully show.

In conclusion, the international community is increasingly recognising that aid can only play a limited role in the improvement of health, and the principal drivers of progress are domestic, including public policies, governance and institutions, education levels and the absence of conflict (Working Party on Aid Effectiveness 2009). It is therefore important to have adequate expectations of how much can be achieved with development assistance.

\section{References}

Acharya, A., A.T. Fuzzo de Lima, and M. Moore (2006). 'Proliferation and Fragmentation: Transaction Costs and the Value of Aid'. Journal of Development Studies, 42: 1-21.

Aldasoro, I., P. Nunnenkamp, and R. Thiele (2010). 'Less Aid Proliferation and More Donor Coordination? The Wide Gap between Words and Deeds'. Journal of International Development, 22: 920-40.

Alonso, J. A. (2004). 'El Desarrollo como Proceso Abierto al Aprendizaje'. European Journal of Development Research, 16: 845-67.

Arndt, C., S. Jones, and F. Tarp (2011). 'Aid Effectiveness: Opening the Black Box'. UNU-WIDER Working Paper No. 2011/44. Helsinki: UNU-WIDER. 
Balabanova, D., M. McKee, A. Mills, G. Walt, and A. Haines (2010). 'What can global health institutions do to help strengthen health systems in low income countries?' Health Research Policy and Systems, 8, 22

Battistella Nemes, M., J. Beaudoin, S. Conway, G. W. Kivumbi, A. Skjelmerud, and U. Vogel (2006). 'Evaluation of WHO's Contribution to '“3 by 5': Main Report'. Geneva: World Health Organization.

Biesma, R.G., R. Brugha, A. Harmer, A. Walsh, N. Spicer, and G. Walt (2009). 'The effects of global health initiatives on country health systems: a review of the evidence from HIV/AIDS control'. Health Policy Plan, 24: 239-52.

Bobba, M., and A. Powell (2007). 'Aid and Growth: Politics Matters'. RES Working Paper No. 4511. Washington DC: Inter-American Development Bank Research Department.

Boone, P. (1996) 'Politics and the Effectiveness of Foreign Aid'. European Economic Review, 40: 289-329.

Bourguignon, F., and D. Leipziger (2006). 'Aid, Growth, and Poverty Reduction: Toward a New Partnership Model'. Washington DC: The World Bank.

Bourguignon, F., and M. Sundberg (2006). 'Constraints to Achieving the MDGs with Scaled-Up Aid’. New York: United Nations.

Bourguignon, F., and M. Sundberg (2007). 'Aid effectiveness - opening the black box'. American economic review, 97: 316-321.

Brown, K., B. Siddiqi, and M. Sessions (2006). 'Development Aid and the Millennium Challenge Account: Emerging Trends in Appropriations’. Washington DC: Center for Global Development

Burnell, P. (2002). 'Financial Indiscipline in Zambia's Third Republic: The Role of Parliamentary Scrutiny’. Journal of Legislative Studies, 7: 34-64.

Burnside, C. and D. Dollar (1999). 'La ayuda, el sistema de incentivos y la reduccion de la pobreza' (Aid, the Incentive Regime and Poverty Reduction (with Englishlanguate summary). Información Comercial Española Revista de Economía, 778: 3141.

Buse, K. (1999) 'Keeping a tight grip on the reins: donor control over aid coordination and management in Bangladesh'. Health Policy and Planning, 14: 219-28.

Carter, R., and S. Lister (2007). 'Budget support: As good as the strategy it finances'. In L. Pallares (ed.) Social Watch Report 2007: In dignity and rights. Uruguay: Social Watch.

Cassen, R.A.A. (1986). Does aid work? Oxford: Clarendon Press.

Cavagnero, E., C. Lane, D. B. Evans, and G. Carrin (2008). 'Development assistance for health: should policy-makers worry about its macroeconomic impact?' Bull World Health Organ, 86: 864-70.

Cavalli, A., S. I. Bamba, M. N. Traore, M. Boelaert, Y. Coulibaly, K. Polman, M. Prard, and M. van Dormael (2010). 'Interactions between Global Health Initiatives and country health systems: the case of a neglected tropical diseases control program in Mali’. Public Library of Science Neglected Tropical Diseases, 4: e798. 
Celasun, O., and J. Walliser (2006). 'Predictability of Budget Aid: Recent Experiences. In: Budget Support as More Effective Aid? Recent Experiences and Emerging Lessons. Koeberle, Stefan. Stavreski, Zoran. Walliser, Jan, eds., Washington DC: World Bank.

Celasun, O., and J. Walliser (2008). 'Predictability of Aid: Do Fickle Donors Undermine Aid Effectiveness?’. Economic Policy, 23: 545-94.

Chansa, C., J. Sundewall, D. McIntyre, G. Tomson, and B. C. Forsberg (2008). 'Exploring SWAp's contribution to the efficient allocation and use of resources in the health sector in Zambia'. Health Policy Plan, 23: 244-51.

Chenery, H., and S. Strout (1966). 'Foreign Assistance and Economic Development'. American Economic Review, 66: 679-753.

Clemens, M., S. Radelet, and R. Bhavnani (2004). 'Counting Chickens when They Hatch: The Short Term Effect of Aid on Growth'. Center for Global Development Working Paper No. 44. Washington DC: Center for Global Development.

Clemens, M.A., and T.J. Moss (2005). 'Ghost of 0.7\%: Origins and relevance of the international aid target’. Washington, D.C.: Center for Global Development.

Cohen, J. M., O. Sabot, K. Sabot, M. Gordon, I. Gross, D. Bishop, M. Odhiambo, Y. Ipuge, L. Ward, A. Mwita, and C. Goodman (2010). 'A pharmacy too far? Equity and spatial distribution of outcomes in the delivery of subsidized artemisinin-based combination therapies through private drug shops'. BMC Health Serv Res, 10: Suppl 1 , S6.

De Renzio, P. (2005) 'Scaling up versus absorptive capacity: challenges and opportunities for reaching the MDGs in Africa'. ODI Briefing Paper. London: Overseas Development Institute.

De Renzio, P. (2007) 'Aid effectiveness and absorptive capacity: which way aid reofrm and accountability?’, ODI Opinions. London: Overseas Development Institute.

Denizer, C., D. Kaufmann, and A. Kraay (2011). 'Good countries or good projects? macro and micro correlates of World Bank project performance’. World Bank Policy Research Working Paper No. 5646. Washington DC: World Bank.

Dodd, R., and C. Lane (2010). 'Improving the long-term sustainability of health aid: are Global Health Partnerships leading the way?’ Health Policy and Planning, 25: 363371.

Dollar, D., and W. Easterly (1999). 'The Search for the Key: Aid, Investment and Policies in Africa'. Journal of African Economies, 8: 546-77.

Dom, C. (2007). 'What are the effects of General Budget Support? The Joint Evaluation of General Budget Support 1994-2004’. Glasgow: Organisation for Economic Cooperation and Development.

Doucouliagos, H., and M. Paldam (2011). 'The Ineffectiveness of Development Aid on Growth: An Update'. European journal of political economy, 27: 399-404.

Dreher, A., P. Nunnenkamp, P., and R. Thiele (2011). 'Are 'New' Donors Different? Comparing the Allocation of Bilateral Aid Between nonDAC and DAC Donor Countries'. World Development, 39: 1950-68. 
Easterly, W.E. (2002). 'The Cartel of Good Intentions: Bureaucracy vs. Markets in Foreign Aid'. Center for Global Development Working Paper No. 4, Center for Global Development.

Easterly, W.E. (2008). Reinventing Foreign Aid, Foreword by Nancy Birdsall. Cambridge and London: MIT Press.

Ebrahim, A. (2003). 'Accountability in practice: Mechanisms for NGOs'. World Development, 31: 813-29.

Ebrahim, A. (2005). 'Accountability myopia: Losing sight of organizational learning'. Nonprofit and Voluntary Sector Quarterly, 34: 56-87.

Ebrahim, A. (2010). 'The Many Faces of Nonprofit Accountability’. Harvard Business School.

Edwards, M., and D. Hulme (1996). 'Too Close for Comfort? The Impact of Official Aid on Non-Governmental Organizations'. World Development, 24: 961-73.

Eyben, R. (2006). Relationships for aid. London: Earthscan.

Farag, M., A. K. Nandakumar, S. S. Wallack, G. Gaumer, and D. Hodgkin (2009). 'Does funding from donors displace government spending for health in developing countries?’ Health Aff (Millwood), 28: 1045-55.

Feeny, S., and M. McGillivray (2011). 'Scaling-Up Foreign Aid: Will the "Big Push" Work?’ World Economy, 34: 54-73.

Feldbaum, H., and J. Michaud (2010). 'Health Diplomacy and the Enduring Relevance of Foreign Policy Interests'. Public Library of Science Medicine, 7

Feyzioglu, T., V. Swaroop, and M. Zhu (1998). 'A Panel Data Analysis of the Fungibility of Foreign Aid’. World Bank Economic Review, 12: 29-58.

Foster, M., and J. Leavy (2001). 'The Choice of Financial Aid Instruments'. London: Overseas Development Institute.

Frenk, J., J. Sepulveda, O. Gomez-Dantes, and F. Knaul (2003). 'Evidence-based health policy: three generations of reform in Mexico’. Lancet, 362: 1667-71.

Frot, E., and J. Santiso (2008). 'Development Aid and Portfolio Funds: Trends, volatility and Fragmentation’. OECD Working Paper No. 275. Paris: Organization for Economic Development and Co-operation.

Frot, E., and J. Santiso (2010). 'Crushed Aid: Fragmentation in Sectoral Aid'. OECD Development Centre Working Papers 284. Organization for Economic Development and Co-operation.

Gibson, C. C., K. Andersson, E. Ostrom, and S. Shivakumar (2005). The Samaritan's Dilemma: The Political Economy of Development Aid. Oxford and New York: Oxford University Press.

Gottret, P., and G. Schieber (2006). 'Health Financing Revisited - A Practitioner's Guide’. Washington DC: World Bank.

Haan, A. (2009) 'Aid: the drama, the fiction, and does it work?'. Institute of Social Studies, Working Paper No. 488. 
Halonen, M. (2004). 'Coordination Failure in Foreign Aid'. Policy Research Working Paper No.3223. Washington DC: World Bank.

Hansen, H., and F. Tarp (2000). 'Aid Effectiveness Disputed'. Journal of International Development, 12: 375-98.

Hanson, K., M. Ranson, V. Oliveria-Cruz, and A. Mills (2003). 'Expanding access to priority health interventions: a framework for understanding the constraints to scaling up’. Journal of International Development, 15: 1-14.

Harrold, P. and associates (1995). 'The broad sector approach to investment lending: sector investment programs’. World Bank Discussion Paper No. 302.

Heady, D.D. (2007). 'Geopolitics and the Effect of Foreign Aid on Economic Growth: 1970-2001'. Journal of International Development, 20: 161-180

Hines, J.R., and R.H. Thaler (1995). 'The Flypaper Effect'. Journal of Economic Perspectives, 9: 217-26.

Holvoet, N., and R. Renard (2007). 'Monitoring and Evaluation Reform under Changing Aid Modalities: Seeking the Middle Ground in Aid-Dependent LowIncome Countries. UNU-WIDER Working Paper No. 2007/53. Helsinki: UNUWIDER.

Hutton, G., and M. Tanner (2004). 'The sector-wide approach: a blessing for public health?’ Bull World Health Organ, 82: 893.

Institute of Health Metrics and Evaluation (2010). 'Financing Global Health 2010: Development assistance and country spending in economic uncertainty'. Seattle: IHME.

Institute for Health Metrics and Evaluation (2011). 'Financing Global Health 2011: Continued Growth as MDG Deadline Approaches’. Seattle: IHME.

International Monetary Fund (2007). 'Fiscal Policy Response to Scaled-up Aid'. Washington DC: International Monetary Fund

Juliet, N.O., S. Freddie, and S. Okuonzi (2009). 'Can donor aid for health be effective in a poor country? Assessment of prerequisites for aid effectiveness in Uganda'. Pan African Medical Journal, 3:9.

Juselius, K., N.F. Moller, and F. Tarp (2011). 'The Long-Run Impact of Foreign Aid in 36 African Countries: Insights from Multivariate Time Series Analysis’. UNUWIDER Working Paper No. 2011/51. Helsinki: UNU-WIDER

Kapur, D., and D. Whittle (2010). 'Can the Privatization of Foreign Aid Enhance Accountability?’ New York University Journal of International Law and Politics, 42: 1143-80.

Knack, S., and A. Rahman (2007). 'Donor fragmentation and bureaucratic quality in aid recipients'. Journal of Development Economics, 83: 176-97.

Labonte, R., and M.L. Gagnon (2010). 'Framing health and foreign policy: lessons for global health diplomacy'. Global Health, 6, 14.

Lahiri, S., and P. Raimondos-Moller (2004). 'Donor Strategy under the Fungibility of Foreign Aid'. Economics and Politics, 16: 213-31. 
Lancaster, C. (1999). 'Aid Effectiveness in Africa: The Unfinished Agenda'. Journal of African Economics, 8: 1045-1055.

Leader, N., and P. Colenso (2005). 'Aid Instruments in Fragile States'. Poverty Reduction in Difficult Environments Working Paper No. 5. London: UK Department for International Development.

Levine, R. (2004). 'Millions Saved: Proven Successes in Global Health’. In: Kinder, M. (ed.) What Works Working Group. Washington DC: Centre for Global Development.

Lieberman, S., P. Gottret, E. Yeh, J. De Beyer, R. Oelrichs, and D. Zewdie (2009). 'International health financing and the response to AIDS'. Journal of Acquired Immune Deficiency Syndromes, 52 Suppl 1: S38-44.

Lu, C., M.T. Schneider, P. Gubbins, K. Leach-Kemon, D. Jamison, and C. J. Murray (2010). 'Public financing of health in developing countries: a cross-national systematic analysis’. Lancet, 375: 1375-87.

Mackellar, L. (2005). 'Priorities in global assistance for health, AIDS, and population. Population and Development Review, 31: 293-312.

Mangham, L. J., and K. Hanson (2010). 'Scaling up in international health: what are the key issues?’ Health Policy Plan, 25: 85-96

Marshall, J., and E. Ofei-Aboagye (2004). 'Donors and childhood poverty in sub Saharan Africa: Approaches and aid mechanisms in Ghana and Tanzania'. London: Childhood Poverty Research and Policy Centre.

Martinez, J. (2008). ;Sector-wide approaches at critical times: the case of Bangladesh'. London: HLSP Institute

Masanja, H., D. de Savigny, P. Smithson, J. Schellenberg, T. John, C. Mbuya, G. Upunda, T. Boerma, C. Victoria, T. Smith, H. Mshinda (2008). 'Child Survival Gains in Tanzania: Analysis of Data from Demographic and Health Services'. Lancet, 371: 1276-83.

McCoy, D., S. Chand, and D. Sridhar (2009). 'Global health funding: how much, where it comes from and where it goes'. Health Policy and Planning, 24: 407-17.

McGillivray, M., and O. Morrissey (2000). 'Aid Fungibility in Assessing Aid: Red Herring or True Concern?’. Journal of International Development, 12: 413-28.

Medlin C. A., M. Chowdhury, D. T. Jamison , A. R. Measham (2006). 'Improving the health of populations: lessons of experience'. In D.T. Jamison J.G. Breman, A.R. Measham (eds) Disease Control Priorities in Developing Countries. Second Edition. New York: Oxford University Press.

Minoiu, C. and S.G. Reddy (2010). 'Development aid and economic growth: A positive long-run relation'. The Quarterly Review of Economics and Finance 50: 27-39.

Mishra, P., and D. Newhouse (2007). 'Health Aid and Infant Mortality'. Washington DC: International Monetary Fund.

Monkam, N.F.K. (2008). 'The Money-Moving Syndrome and the Effectiveness of Foreign Aid'. PhD thesis. Georgia State University. 
Moore, A., and J. Morrison (2007). 'Health Worker Shortages Challenge PEPFAR Options for Strengthening Health Systems’. Washington: Center for Strategic and International Studies.

Mueller, D.H., D. Lungu, A. Acharya, and N. Palmer (2011). 'Constraints to implementing the Essential Health Package in Malawi'. Public Library of Science One, 6: e20741.

Munishi, G. (2003). 'Intervening to address constraints through health sector reforms in Tanzania: some gains and the unfinished business'. Journal of International Development, 15: 115-31.

NORAD (2008). 'Support Models for CSOs at Country Level'. Oslo: Norwegian Agency for Development Co-operation.

Nugent, R. A. (2010). 'Where Have All the Donors Gone? Scarce Donor Funding for Non-Communicable Diseases’. Washington DC: Center for Global Development.

Overseas Development Administration (1993). Taking account of good government. London: Overseas Development Administration.

Overseas Development Institute and Mokoro (2009). 'Sector Budget Support in Practice Case Study: Health Sector in Zambia’. London and Oxford: Overseas Development Institute and Mokoro.

OECD (2008a). 2008 survey on monitoring the Paris Declaration. Effective aid by 2010? What will it take. Overview Vol. 1. Paris and Washington DC: OECD.

OECD (2008b). 2008 Survey on Monitoring the Paris Declaration: Making Aid More Effective by 2010: Better Aid. Paris: Organization for economic co-operation and development.

Ooms, G., K. Decoster, K. Miti, S. Rens, L. van Leemput, P. Vermeiren, and W. van Damme (2010). 'Crowding out: are relations between international health aid and government health funding too complex to be captured in averages only?'. Lancet, 375: $1403-5$.

Ooms, G., W. van Damme, B.K. Barker, P. Zeitz, and T. Schrecker (2008). 'The 'diagonal' approach to Global Fund financing: a cure for the broader malaise of health systems?'. Global Health, 4: 6.

Pack, H., and J.R. Pack (1993). 'Foreign Aid and the Question of Fungibility'. Review of Economics and Statistics, 75: 258-65.

Pettersson, J. (2007). 'Child Mortality: Is Aid Fungibility in Pro-poor Expenditure Sectors Decisive?'. Review of World Economics/Weltwirtschaftliches Archiv, 143: 673-93.

Piva, P., R. Dodd (2009). 'Where did all the aid go? An in-depth analysis of increased health aid flows over the past 10 years'. Bulletin of the World Health Organization, 87:930-939

Quartey, P. (2005). 'Innovative ways of making aid effective in Ghana: tied aid versus direct budgetary support’. Journal of international development, 17: 1077-1092.

Rajan, R., and A. Subramanian (2005). 'Aid and Growth: What Does the Cross-Country Evidence Really Show?’ IMF Working Papers 05/127. International Monetary Fund. 
Rajan, R., and A. Subramanian (2008). 'Aid and Growth: What Does the Cross-Country Evidence Really Show?’ The Review of Economics and Statistics, 90: 643-665.

Rao Seshadri, S. (2003). 'Constraints to scaling up health programmes: a comparative study of two Indian states’. Journal of International Development, 15: 101-114.

Ravishankar, N., P. Gubbins, P., R. J. Cooley, K. Leach-Kemon, C. M. Michaud, D. T. Jamison, and C. J. Murray (2009). 'Financing of global health: tracking development assistance for health from 1990 to 2007’. Lancet, 373: 2113-24.

Renju, J.R., A.B.A. Bahati, L. Medard, C. Kishamawe, M. Kimaryo, J. Changalucha, and A. Obasi (2011). 'Scaling-up adolescent sexual and reproductive health interventions through existing government systems? A detailed process evaluation of a school-based intervention in Mwanza Region in the Northwest of Tanzania'. Journal of Adolescent Health, 48: 79-86.

Rodrik, D. (2010). 'Diagnostics before prescriptions'. The Journal of Economic Perspectives, 24: 33-44.

Schwartlander, B., I. Grubb, and J. Perriens (2006). 'The 10-year struggle to provide antiretroviral treatment to people with HIV in the developing world'. The Lancet, 368: 541-546.

Shiffman, J. (2006a). 'Donor funding priorities for communicable disease control in the developing world'. Health Policy and Planning, 21: 411-20.

Shiffman, J. (2006b). 'HIV/AIDS and the rest of the global health agenda'. Bulletin of the World Health Organization, 84, 923.

Shiffman, J. (2008). 'Has donor prioritization of HIV/AIDS displaced aid for other health issues?' Health Policy and Planning, 23: 95-100.

Shiffman, J., T. Beer, and Y. Wu (2002). 'The emergence of global disease control priorities’. Health Policy and Planning, 17: 225-34.

Spicer, N., J. Aleshkina, R. Biesma, R. Brugha, C. Caceres, B. Chilundo, K. Chkhatarashvili, A. Harmer, P. Miege, G. Murzalieva, P. Ndubani, N. Rukhadze, T. Semigia, A. Walsh, G. Walt, and X, Zhang (2010). 'National and subnational HIV/AIDS co-ordination: are global health initiatives closing the gap between intent and practice?’. Global Health, 6: 3.

Sridhar, D., and N. Woods (2010). 'Are there simple conclusions on how to channel health funding?’. Lancet, 375: 1326-8

Strategic Partnership for Africa - Budget Support Working Group (2005). 'Survey of the Alignment of Budget Support and Balance of Payments Support with National PRS Processes'. Brussels and London.

Stuckler, D., S. Basu, and M. McKee (2011). 'International Monetary Fund and aid displacement'. International Journal of Health Services, 41: 67-76.

Sundewall, J., B. C. Forsberg, K. Jonsson, C. Chansa, and G. Tomson (2009). 'The Paris Declaration in practice: challenges of health sector aid coordination at the district level in Zambia'. Health Research Policy and Systems, 7: 14. 
Sundewall, J., and K. Sahlin-Andersson (2006). 'Translations of health sector SWAps-a comparative study of health sector development cooperation in Uganda, Zambia and Bangladesh'. Health Policy, 76: 277-87

van de Walle, D., and R. Mu (2007). 'Fungibility and the Flypaper Effect of Project Aid: Micro-evidence for Vietnam'. Journal of Development Economics, 84: 667-85.

Vassall, A., and Martínez Álvarez, M. (2011). 'The health system and external financing'. In: Smith, R. D., and K. Hanson. (eds.) Health Systems in low- and middle-income countries: An economic and policy perspective. Oxford University Press.

Waddington, C. (2004). 'Does earmarked donor funding make it more or less likely that developing countries will allocate their resources towards programmes that yield the greatest health benefits?'. Bulletin of the World Health Organization, 82: 703-708.

Wagstaff, A. (2011). 'Fungibility and the Impact of Development Assistance: Evidence from Vietnam's Health Sector'. Journal of Development Economics, 94: 62-73.

White, H. (2007). 'The Bangladesh Health SWAp: Experience of a New Aid Instrument in Practice’. Development Policy Review, 25: 451-72.

Williamson, T., and C. Dom (2010). 'Making sector budget support work for service delivery: an overview’. London: Overseas Development Institute.

Wood, B., J. Betts, F., Etta, F., Gayfer, J., D. Kabell, N. Ngwira, F. Sagasti, and M. Samaranayake (2011). 'The Evaluation of the Paris Declaration: Final report'. Copenhagen.

Working Party on Aid Effectiveness (2009). 'Aid for Better Health: What are we learning about what works and what we still have to do?'. Paris: OECD

World Bank (1998). 'Assessing Aid: What Works, What Doesn't, and Why. New York: Oxford University Press.

World Bank (2006). 'Global Monitoring Report 2006: Millennium Development Goals: Strengthening Mutual Accountability, Aid, Trade, and Governance’. Washington DC: World Bank.

World Health Organization Maximizing Positive Synergies Collaborative Group, B. Samb, T. Evans, M. Dybul, R. Atun, J. P. Moatti, S. Nishtar, A. Wright, F. Celletti, J. Hsu, J. Y. Kim, R. Brugha, A. Russell, and C. Etienne (2009). 'An assessment of interactions between global health initiatives and country health systems'. Lancet, 373: 2137-69.

Wyss, K., D. D. Moto, and B. Callewaert (2003). 'Constraints to scaling up health related interventions: the case of Chad, Central Africa'. Journal of International Development, 15: 87-100.

Yu, D., Y. Souteyrand, M. Banda, J. Kaufman, and J. Perries (2008). 'Investment in HIV/AIDS programs: does it help strengthen health systems in developing countries?' Globalization and Health, 4:8. 